\title{
Cell death attenuation by 'Usurpin', a mammalian DED- caspase homologue that precludes caspase-8 recruitment and activation by the CD-95 (Fas, APO-1) receptor complex
}

Dita M. Rasper ${ }^{1}$, John P. Vaillancourt', Shinji Hadano ${ }^{5,6}$, Vicky M. Houtzager ${ }^{1}$, Isolde Seiden ${ }^{1}$, Sabina L.C. Keen ${ }^{1}$, Paul Tawa ${ }^{1}$, Steve Xanthoudakis ${ }^{1}$, Jamal Nasir ${ }^{5}$, Duane Martindale ${ }^{7}$, Ben F. Koop ${ }^{7}$, Erin P. Peterson ${ }^{3}$, Nancy A. Thornberry ${ }^{3}$, JingQi Huang ${ }^{2}$,

David P. MacPherson ${ }^{2}$, Shawn C. Black ${ }^{2}$, Felicita Hornung ${ }^{4}$, Michael J. Lenardo ${ }^{4}$, Michael R. Hayden ${ }^{5}$, Sophie Roy ${ }^{1}$ and Donald W. Nicholson ${ }^{1,8}$

${ }^{1}$ Department of Biochemistry and Molecular Biology, Merck Frosst Centre for Therapeutic Research, Pointe Claire-Dorval, Quebec, Canada, H9R 4P8

2 Department of Pharmacology, Merck Frosst Centre for Therapeutic Research, Pointe Claire-Dorval, Quebec, Canada, H9R 4P8

${ }^{3}$ Department of Enzymology, Merck Research Laboratories, Rahway, New Jersey, 07065, USA

${ }^{4}$ Laboratory of Immunology, National Institute of Allergy and Infectious Diseases, National Institutes of Health, Bethesda, Maryland, 20892-1892, USA

${ }^{5}$ Department of Medical Genetics, University of British Columbia, Canadian Genetic Diseases Network, Centre for Molecular Medicine and Therapeutics, Vancouver, British Columbia, Canada V6T 1 Z4

${ }^{6}$ NeuroGenes, International Cooperative Research Project, Japan Science and Technology Corporation, Tokai University School of Medicine, Kanagawa 25911, Japan

7 Centre for Environmental Health, Department of Biology, University of Victoria, Victoria, British Columbia, Canada V8W 3N5

8 corresponding author: Department of Biochemistry and Molecular Biology, Merck Frosst Centre for Therapeutic Research, PO box 1005, Pointe ClaireDorval, Quebec, Canada, H9R 4P8; e-mail: donald_nicholson@merck.com; tel: (514) 428-8544; fax: (514) 695-0693

Received 29.10.97; revised 15.12.97; accepted 5.1.98

Edited by G. Melino

\begin{abstract}
Apoptotic cell suicide initiated by ligation of CD95(Fas/APO-1) occurs through recruitment, oligomerization and autocatalytic activation of the cysteine protease, caspase-8 $(\mathrm{MACH}$, FLICE, Mch5). An endogenous mammalian regulator of this process, named Usurpin, has been identified (aliases for Usurpin include CASH, Casper, CLARP, FLAME-1, FLIP, IFLICE and MRIT). This protein is ubiquitously expressed and exists as at least three isoforms arising by alternative mRNA splicing. The Usurpin gene is comprised of 13 exons and is clustered within approximately $200 \mathrm{~Kb}$ with the caspase-8 and -10 genes on human chromosome 2q33-34. The Usurpin polypeptide has features in common with pro-caspase-8 and -10 , including tandem 'death effector domains' on the $\mathrm{N}$ terminus of a large subunit/small subunit caspase-like domain, but it lacks key residues that are necessary for caspase proteolytic activity, including the His and Cys which form the catalytic substrates diad, and residues that stabilize the $P_{1}$ aspartic acid in substrates. Retro-mutation of these
\end{abstract}

residues to functional caspase counterparts failed to restore proteolytic activity, indicating that other determinants also ensure the absence of catalytic potential. Usurpin heterodimerized with pro-caspase-8 in vitro and precluded procaspase-8 recruitment by the FADD/MORT1 adapter protein. Cell death induced by CD95 (Fas/APO-1) ligation was attenuated in cells transfected with Usurpin. In vivo, a Usurpin deficit was found in cardiac infarcts where TUNEL-positive myocytes and active caspase-3 expression were prominent following ischemia/reperfusion injury. In contrast, abundant Usurpin expression (and a caspase-3 deficit) occurred in surrounding unaffected cardiac tissue, suggesting reciprocal regulation of these pro- and anti-apoptotic molecules in vivo. Usurpin thus appears to be an endogenous modulator of apoptosis sensitivity in mammalian cells, including the susceptibility of cardiac myocytes to apoptotic death following ischemia/ reperfusion injury.

Keywords: apoptosis; caspase; CD95 (Fas, APO-1); ischemia/ reperfusion injury

Abbreviations: caspase, cysteinyl aspartate-specific proteinase; DED, death effector domain; Usurpin, usurps caspase-8 inhibits cell death

\section{Introduction}

Individual cells within multicellular organisms commit suicide in a highly ordered and systematic process which involves a biochemical 'cell death' pathway that has been largely conserved throughout evolution. This form of altruistic cell suicide, which is manifest as the apoptotic phenotype, occurs during developmental morphogenesis, in the removal of expended, unnecessary or irreparably damaged cells, and in response to pathogenic infections (Kerr et al, 1972; McConkey et al, 1996; Steller, 1995; Thompson, 1995; Uren and Vaux, 1996).

Apoptotic cell suicide proceeds through a highly regulated series of biochemical events and many of the components of the cell death pathway have been recently identified. At the heart of this pathway lies a family of cysteine proteases, the caspases, which are related to mammalian interleukin-1 $\beta$ converting enzyme (ICE/caspase-1) and the product of the C. elegans 'death gene', CED-3 (Alnemri et al, 1996; Cohen, 1997; Nicholson and Thornberry, 1997). The caspases mediate apoptosis by cleaving a discrete subset of homeostatic, repair and structural proteins within dying cells which results in the cessation of normal cellular functions, the dismantling of the genome and structural constituents of the 
cell, and the packaging of cellular components into apoptotic corpses for engulfment by other cells (Nicholson and Thornberry, 1997; Rosen and Casciola-Rosen, 1997). The central importance of caspases in these processes has been demonstrated with both macromolecular and peptide-based inhibitors, which prevent apoptosis from occurring in vitro and in vivo, as well as by genetic approaches (Bump et al, 1995; Devereaux et al, 1997; Hara et al, 1997; Kuida et al, 1996; Liston et al, 1996; Loddick et al, 1996; Nicholson et al, 1995; Xue and Horvitz, 1995; Zhou et al, 1997).

Ten caspases have so far been identified in human cells. Each is synthesized as a catalytically dormant proenzyme containing an amino-terminal prodomain followed by the large and small subunits of the heterodimeric active enzyme. The subunits are excised from the proenzyme by cleavage at Asp-X junctions. The strict requirement by caspases for Asp in the $P_{1}$ position of substrates is consistent with a mechanism whereby proenzyme maturation can be either autocatalytic or performed by other caspases. The three dimensional crystal structures of mature caspase- 1 and -3 show that the large subunit contains the principle components of the catalytic machinery, including the active site Cys residue which is harbored within the conserved pentapeptide motif, QACxG, and residues that stabilize the oxyanion of the tetrahedral transition state (Rotonda et al, 1996; Walker et al, 1994; Wilson et al, 1994). Both subunits contribute residues which stabilize the $P_{1}$ Asp of substrates while the small subunit appears to contain most of the determinants that dictate substrate specificity and, in particular, those which form the specificity-determining $\mathrm{S}_{4}$ subsite.

Members of the caspase family can be divided into three functional subgroups based on their substrate specificities which have been defined by a positional-scanning combinatorial substrate approach (Rano et al, 1997; Thornberry et al, 1997). The principle effectors of apoptosis (group II caspases, which include caspases-2, -3 and -7 as well as C. elegans CED-3) have specificity for $\left[\mathrm{P}_{4}\right] \mathrm{DExD}\left[\mathrm{P}_{1}\right]$, a motif found at the cleavage site of most proteins known to be cleaved during apoptosis (Nicholson and Thornberry, 1997). On the other hand, the specificity of group III caspases (caspases-6, -8, -9 and -10 , as well as CTL-derived granzyme $B)$ is $\left[P_{4}\right](I, V, L) E x D\left[P_{1}\right]$ which corresponds to the activation site at the junction between the large and small subunits of other caspase proenzymes including group II (effector) family members. This and other evidence indicates that group III caspases function as upstream activators of group II caspases in a proteolytic cascade that amplifies the death signal. The mechanism by which at least one of the group III activator caspases is itself activated (caspase-8/MACH, FLICE, Mch5) has been elucidated by studies on the CD95 (Fas/APO-1) receptor system (Boldin et al, 1996; Medema et al, 1997; Muzio et al, 1996).

CD95 (Fas/APO-1) is a member of the growing family of 'death receptors' which also includes TNF-R1, TRAIL-R/DR4/APO-2, TRAIL-R2/DR-5 and TRAMP/DR-3/APO-3/ws1/ AIR/LARD. In addition to overall structural similarities, these receptors have in common the ability to communicate a proapoptotic signal via carboxy-terminal cytoplasmic 'death domains' (DD) (Nagata, 1997; Wallach et al, 1997; Yuan,
1997). In the case of the CD95 (Fas/APO-1) system, receptor ligation by the homotrimeric Fas ligand results in receptor oligomerization and subsequent recruitment of multiple FADD/MORT1 adapter proteins (Boldin et al, 1995; Chinnaiyan et al, 1995) to the receptor complex. The FADD/MORT1 adapters in turn recruit caspase-8 proenzymes which then become activated, presumably by intermolecular autocatalysis following receptor-mediated proenzyme oligomerization. Whereas interactions between CD95 (Fas/APO-1) and the FADD/MORT1 adapter are mediated by the 'death domains' contained within both molecules, the interaction between FADD/MORT1 and the caspase-8 proenzyme are mediated by interactions between homologous 'death effector domains' (DEDs) that are contained in the amino-terminus of FADD/MORT1 as well as within the prodomain of caspase-8. The prodomain of caspase-8 contains two serial DEDs as does the prodomain of caspase-10 (Fernandes-Alnemri et al, 1996). Several viral DED-containing proteins have recently been shown to disrupt the formation of functional death-signaling CD95 (Fas/APO-1) receptor complexes by competing for interactions with the DEDs within either the FADD/MORT1 adapter or the DED-caspase proenzymes, and this appears to be a mechanism by which to delay the host suicide response and facilitate productive viral infection (Bertin et al, 1997; Hu et al, 1997; Thome et al, 1997).

In this report, we describe the molecular cloning and anti-apoptotic activity of an endogenous mammalian regulator of CD95 (Fas/APO-1)-mediated cell death. This molecule, named 'Usurpin' (since it usurps caspase-8 function, by precluding recruitment of the caspase- 8 proenzyme to the death-signaling complex, and inhibits apoptotic cell death), resembles other DED caspases except that it lacks critical residues that are necessary for substrate recognition, binding and subsequent caspase proteolytic activity. Usurpin may play an important role in the regulation of Fas-mediated cell death and thus contribute to lymphocyte homeostasis, memory T-cell formation, immune privilege and tumor immuno-evasion. In addition, it appears to play a protective role in cardiac tissue and may do so in other organ systems as well. Although not addressed in this study, Usurpin may also regulate the pro-apoptotic signaling of other CD95 (Fas/ APO-1)/TNF-R1-like death receptors. During the preparation of this manuscript, Usurpin was also identified by other groups and its aliases include CASH, Casper, CLARP, FLAME-1, FLIP, I-FLICE and MRIT (Goltsev et al, 1997; Han et al, 1997; Hu et al, 1997; Inohara et al, 1997; Irmler et al, 1997; Shu et al, 1997; Srinivasula et al, 1997).

\section{Results}

\section{Cloning of Usurpin and splice variants}

A $3^{\prime}$ fragment of the Usurpin cDNA (IMAGE Consortium no. 427786, zh82c06), corresponding to the region encoding amino acids $180-480$, was initially identified by automated tBLASTn profiler searching of the Merck/Washington University EST collection using all known caspase proenzymes as query sequences. Full length cDNA clones were then 
generated by $5^{\prime}$ RACE PCR and by lambda-phage library screening (human fetal kidney). Three distinct sub-populations of cDNA clones were identified corresponding to alternatively-spliced variants of a single Usurpin gene. The longest clone (Usurpin- $\alpha$ ) encoded a 480 amino acid DED caspase-like polypeptide with significant homology $(26 \%$ identity, $37 \%$ similarity) to pro-caspase-8 and -10 (Figures 1 and 2). Usurpin- $\beta$ contains the first 435 amino acids of Usurpin- $\alpha$ plus 27 non-homologous C-terminal amino acids arising from an additional 835 base exon which introduces these residues and a premature stop codon. Usurpin- $\gamma$, the shortest variant identified, is composed of the first 264 residues of the Usurpin- $\alpha$ sequence plus 28 non-homologous
C-terminal residues owing, in this case, to an additional 271 base exon which also contains an in frame stop codon. (A fourth population of cDNA clones contained both these inserted exons which would result in the Usurpin- $\gamma$ polypeptide following translation.)

\section{Molecular organization of Usurpin and absence of caspase catalytic determinants}

The Usurpin polypeptide contains both functionally important similarities and differences when compared to the two known DED caspase proenzymes (Figure 1). First, all three contain a long prodomain (approximately 200 amino acids)

A

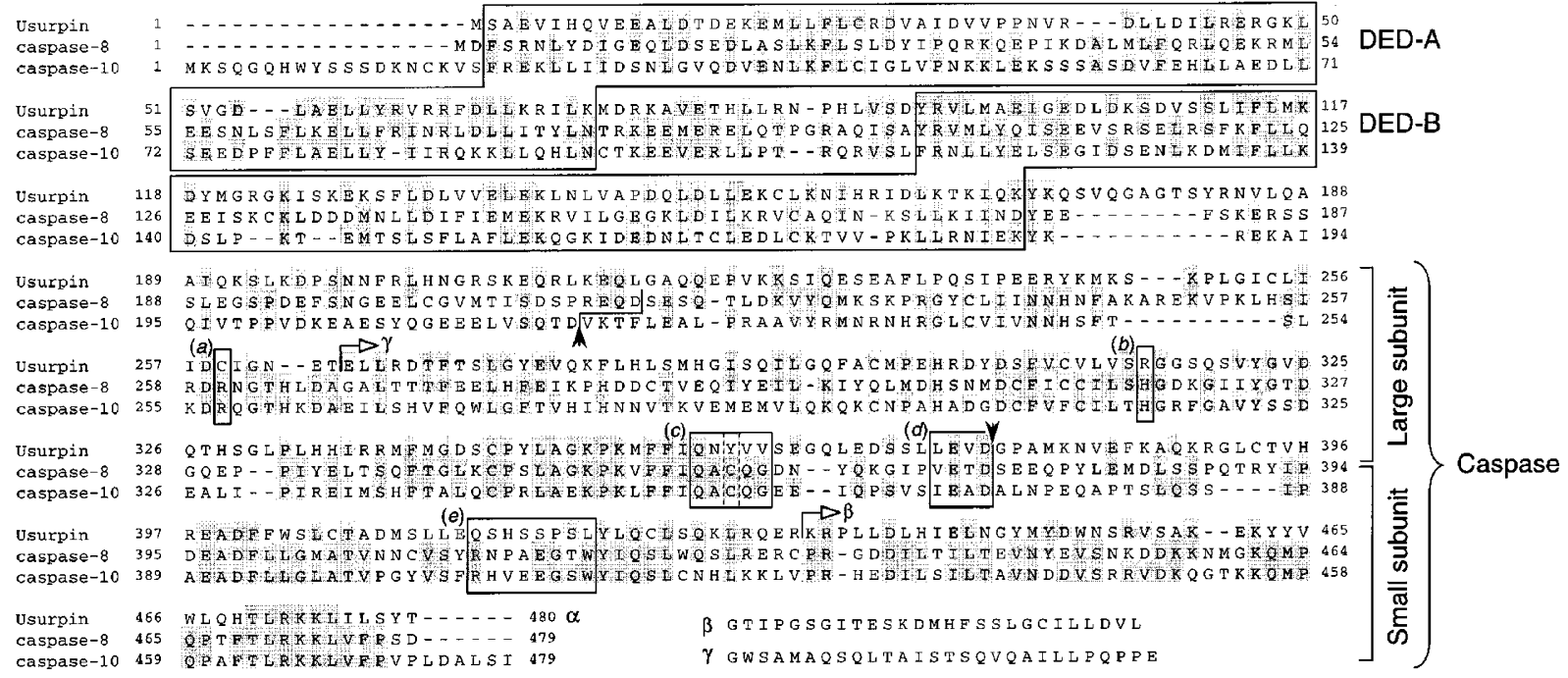

B

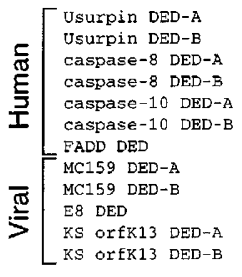

C

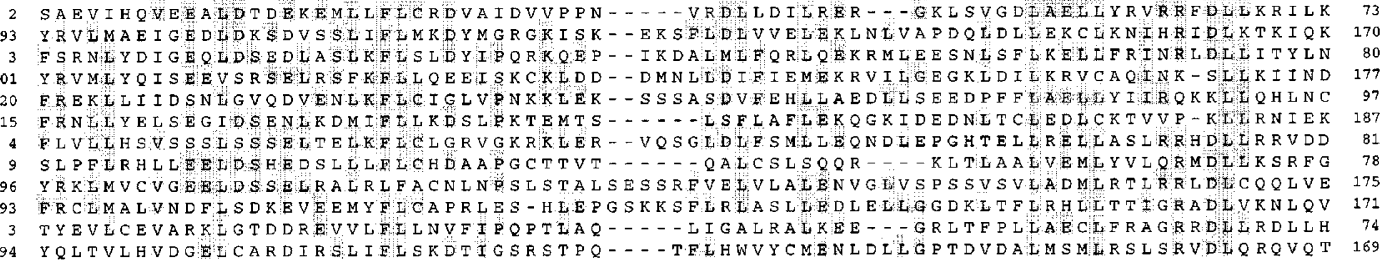

TYEVLCEVARKLGTDDREVVLFLLNVFTRQFTLAQ-- - I IGALRALKEE- - GRLTFPLEAECLFRAGRRDELRDLLH

Figure 1 Primary sequence homology of Usurpin with DED Caspases, but lack of critical catalytic and substrate binding determinants. (A) The Usurpin- $\alpha$ isoform was aligned with the caspase-8 (MACH, FLICE, Mch5) and caspase-10 (Mch4) proenzyme sequences using the 'ClustalW Pileup' algorithm of the Genetic Computer Group (version 9) software package using default alignment parameters. Amino acids that are identical in at least two of the three sequences are shaded. The first (DED-A) and second (DED-B) of the tandem 'death effector domains' are indicated by large boxes, and the regions of the polypeptides corresponding to the large and small subunits of mature caspase enzymes are indicated on the right. The upward-pointing solid arrow indicates the processing sites between the prodomains and large subunits of caspases- 8 and 10, and the downwards-pointing solid arrow indicates the cleavage junction between the large and small subunits. The smaller boxes, labeled a through $e$, contain critical residues that are important for proteolytic catalysis (boxes $b$ and $c$ ) or formation of the $\mathrm{S}_{1}$ subsite (boxes $a$ and $e$ ) which are changed in Usurpin. Box $d$ indicates the group III caspase/granzyme B consensus sites contained in all three polypeptides. The rightwards-pointing open arrows indicate points of departure in the primary amino acid sequences of the two alternative Usurpin isoforms, Usurpin- $\beta$ and Usurpin- $\gamma$, which are composed of the Usurpin- $\alpha$ sequence, to the left of the arrows, contiguous with the amino acid sequences indicated at the bottom of the panel. The cDNA sequences and deduced amino acid sequences for Usurpin isoforms have been deposited in GenBank under accession numbers AF015450 (Usurpin- $\alpha$ ), AF015451 (Usurpin- $\beta$ ) and AF015452 (Usurpin- $\gamma$ ) Unless otherwise indicated, the use of 'Usurpin' in the text refers to the Usurpin- $\alpha$ isoform. (B) Representative human and viral 'Death Effector Domains' (DEDs) were aligned with the DEDs contained within Usurpin. Amino acids that are identical in at least a third of the sequences are shaded. Leucine periodicity, a feature common to other protein:protein interaction domains, is evident in all of the DEDs. (C) The second Usurpin DED (DED-B) contains a region with statistically significant homology to the amino terminus of $C$. elegans CED- 4 ( $27 \%$ identity, $40 \%$ similarity; this has been noted in other DEDs as well (Bauer et al, 1997)) 
that harbor tandem 'death effector domains' (Figure 1b). Second, the prodomains are followed by caspase protease regions which, in each case, contain both the large and small subunit counterparts. Third, the $P_{4}-P_{1}$ tetrapeptide motifs at the activation cleavage sites that separate the large subunits from the small subunits (Figure 1a box $d$ ) perfectly correspond to the substrate recognition sequence for group III caspases $\left(\left[\mathrm{P}_{4}\right](\mathrm{I}, \mathrm{V}, \mathrm{L}) \operatorname{ExD}\left[\mathrm{P}_{1}\right]\right)$. Finally, the high overall primary sequence homology between these three polypeptides substantiates their molecular relatedness.

In contrast to caspases-8 and -10 , however, Usurpin lacks key features that are necessary for substrate binding and catalysis (Figure 1a). First, the proteolytic machinery of all caspases requires a catalytic diad composed of the sulfhydryl group of Cys ${ }^{[\mathrm{ICE}: 285]}$ and the imidazole of His ${ }^{[\mathrm{ICE}: 237]}$. The counterparts of both of these residues in Usurpin are substituted with other amino acids $\left(T_{y r}{ }^{360}\right.$ (Figure 1a box c) and $\operatorname{Arg}^{315}$ (box b), respectively) that would render Usurpin non-functional as a protease. Second, the QACXG pentapeptide motif containing the catalytic Cys residue (box $c$ ), that is conserved in all functional caspase family members across species, contains only the Gln residue (QNYVV). Third, all caspases have a strict requirement for $A s p$ in $P_{1}$ and this near absolute specificity is conferred by four residues, two from each subunit, which stabilize the Asp carboxylate side chain within the $S_{1}$ subsite (Arg ${ }^{\text {[ICE:179], }}$ $\operatorname{GIn}^{[I C E: 283]}, \operatorname{Arg}^{[I C E: 341]}$ and $\left.\operatorname{Ser}^{[I C E: 347]}\right)$. In Usurpin, both of the Arg residues are substituted with uncharged alternates (Cys ${ }^{259}$, box $a$ and $\mathrm{Gln}^{415}$, box $e$ ) whereas the $\operatorname{Gln}^{[\mathrm{ICE}: 283]}$ and Ser ${ }^{[\mathrm{ICE}: 347]}$ counterparts $\left(\mathrm{Gln}^{358}\right.$, box $c$ and $\operatorname{Ser}^{421}$, box $d$, respectively) remain unaltered. Overall, these changes would affect both the chemical nature (loss of three hydrogen bond donors) and geometry of the $S_{1}$ subsite, resulting in a predicted loss of affinity for $P_{1}$ Asp.

Collectively, these four key amino acid changes should render Usurpin catalytically incompetent. This was confirmed experimentally by two approaches: (i) recombinant Usurpin was unable to cleave tetrapeptide-aminomethylcoumarin substrates; and (ii) Usurpin that was overexpressed in bacteria under an inducible ( $L a c Z$ ) promoter (either with or without the prodomain) did not undergo autocatalytic maturation as is normally observed with

A

FADD/MORT1

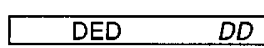

$D D$

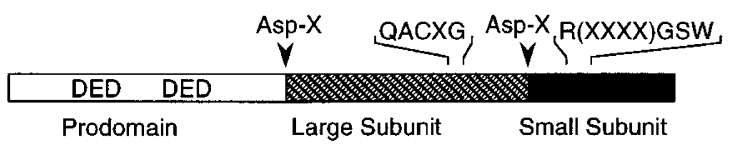

Caspase-8, 10 Proenzyme

Prodomain

Large Subunit

Small Subunit

B

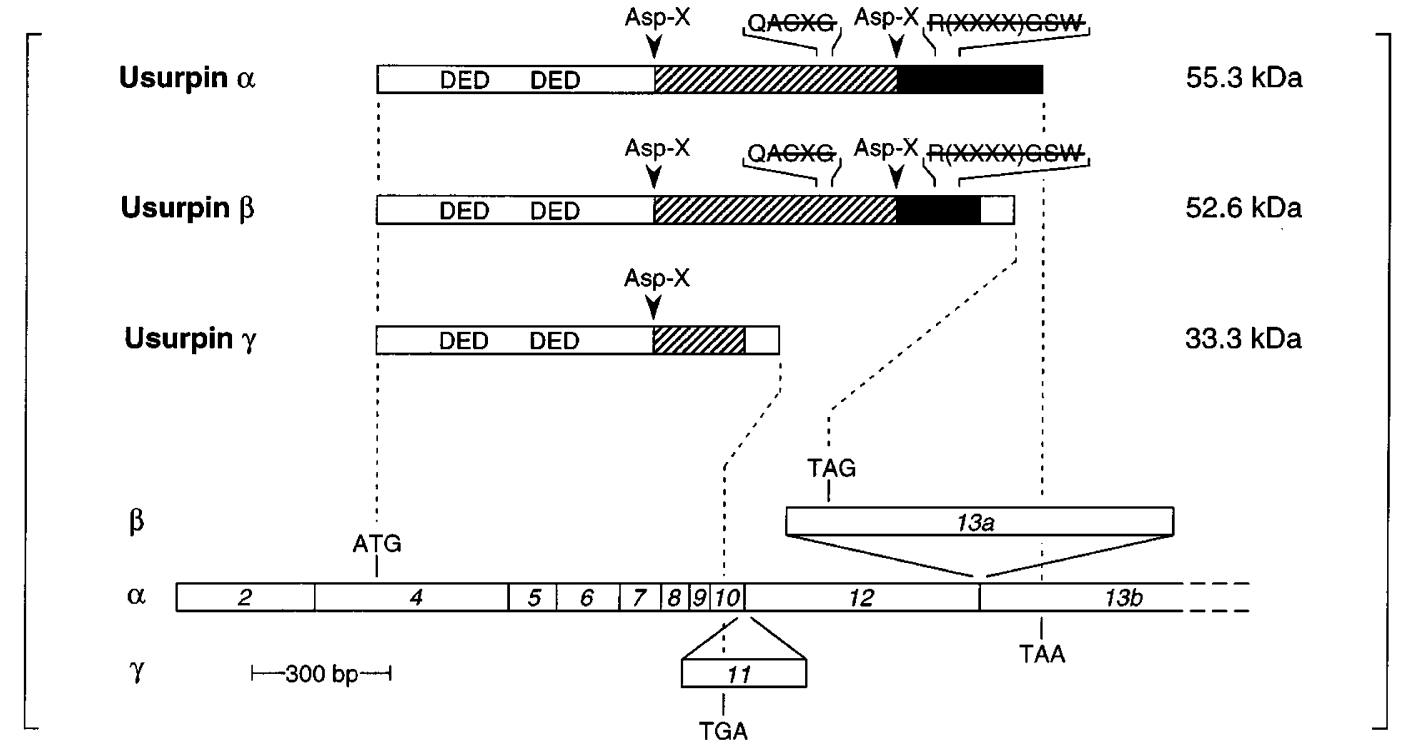

Figure 2 Molecular organization of Usurpin. (A) Bars indicate the key structural components of DED-containing polypeptides and Usurpin (N-terminus left; Cterminus right). The FADD/MORT1 adapter protein contains an N-terminal 'Death Effector Domain' (DED) and a C-terminal 'Death Domain' (DD). Caspases - 8 and 10 proenzymes are formed as larger precursor proteins with an N-terminal prodomain, containing tandem DEDs, plus the large and small subunits which form the active heterodimeric mature enzyme. Separation of these domains during enzyme activation occurs at Asp-X junctions. The large subunit contains the catalytic cysteine residue within a conserved QACxG motif. The small subunit contains substrate specificity determinants, including the RxxxxGSW motif which contributes residues to both the $S_{1}$ and $S_{4}$ subsites. The absence of these motifs (as well as others (see text)) in the three Usurpin variants is represented by strikethrough characters. The calculated molecular mass of each Usurpin variant is indicated at the far right. Unshaded regions at the right of the Usurpin- $\beta$ and Usurpin- $\gamma$ bars indicate areas of the polypeptides that are not identical to Usurpin- $\alpha$ (see Figure 1a). The arrangement of exons (see Figure 5) that generate the three variants is indicated in (B) 
functional caspase proenzymes (not shown). Catalytic activity could not be restored by retro-mutation of these residues in Usurpin to their counterparts in functional caspases (Usurpin: $C^{259} \mathrm{R}$; $\mathrm{R}^{315} \mathrm{H}$; QNYVV ${ }^{358-362} \mathrm{QACQG}$; $Q^{415} R$ ), indicating that other important catalytic determinants are also lacking in Usurpin (not shown).

\section{Genomic organization of the DED-caspase gene cluster}

Using fluorescence in situ hybridization (FISH), Usurpin was mapped to band q33-34 on human chromosome 2 (Figure 3), the same cytogenetic localization as both known DED-containing caspases, caspase-10 (Fernandes-Alnemri et al, 1996) and -8 (unpublished data). The molecular arrangement of the DED-caspase gene cluster was further resolved by direct DNA sequencing and PCR analysis of a $130 \mathrm{~Kb}$ PAC (P1 artificial chromosome) clone containing the Usurpin gene (251L7) (Figure 4). This genomic PAC clone also contained the full gene for caspase-10 and the $5^{\prime}$ UTR of caspase-8, thus defining the positional relationship between these highly related genes. Both the Usurpin and caspase-10 genes contain a similar number of exons (13 and 12, respectively), of which six are very short (37$136 \mathrm{bp})$ and encode the second DED domain and the amino terminus of the large subunit, and two are relatively large and encode the bulk of the caspase-like component. Preliminary results indicate that the gene for caspase- 8 has similar intron/exon organization. Both the Usurpin and caspase-10 genes undergo alternative splicing to give rise to the three Usurpin variants reported herein (Figure $4 \mathrm{~b})$ and the two known caspase-10 variants (caspase-10a (Mch-4) (Fernandes-Alnemri et al, 1996) and caspase-10b
(FLICE2) (Vincenz and Dixit, 1997), respectively) (Figure 4c). The co-localization and similar structural organization of Usurpin and the DED-containing caspases support the likelihood that they arose by tandem gene duplication from a common ancestor, a feature shared by the ICE gene cluster as well (which includes caspase-1 (ICE), caspase-4 $\left(\mathrm{ICE}_{\text {rel- }}{ }^{-I}, \mathrm{TX}, \mathrm{ICH}-2\right)$ and caspase-5 (ICE $\left.\mathrm{rel}^{-1 \mathrm{II}}, \mathrm{TY}\right)$ at 11q22.2-22.3)

\section{Usurpin tissue distribution}

Consistent with the multiple cDNA variants found by library screening, Northern blot analysis indicated that Usurpin is expressed as multiple poly $(\mathrm{A})^{+}$transcripts in both fetal (Figure 5a) and adult tissues (data not shown). Three major transcripts $(6,7$ and $10 \mathrm{~Kb})$ as well as less abundant smaller transcripts were observed in a variety of human organs. Usurpin transcripts were particularly abundant in cardiac and skeletal muscle, differing from the distribution of caspase-8 and -10 transcripts (Boldin et al, 1996; Fernandes-Alnemri et al, 1996; Muzio et al, 1996; Vincenz and Dixit, 1997). Western blot analysis of human tissue homogenates confirmed the abundance of Usurpin polypeptides in heart and skeletal muscle as well as its presence in other organs with the exception of colon, placenta and testis (Figure 5b). Although Usurpin transcripts could not be detected in brain by Northern blot analysis, the protein was clearly detectable on Western blots. The $55.3 \mathrm{kDa}$ Usurpin- $\alpha$ isoform was the dominant polypeptide in all organs containing Usurpin, with the exception of spleen. A smaller protein, corresponding approximately in mass to the $33.3 \mathrm{kDa}$ Usurpin- $\gamma$ isoform, was present with a highly restricted distribution in lymphoid tissues (thymus, lymph node and spleen). Usurpin- $\beta$
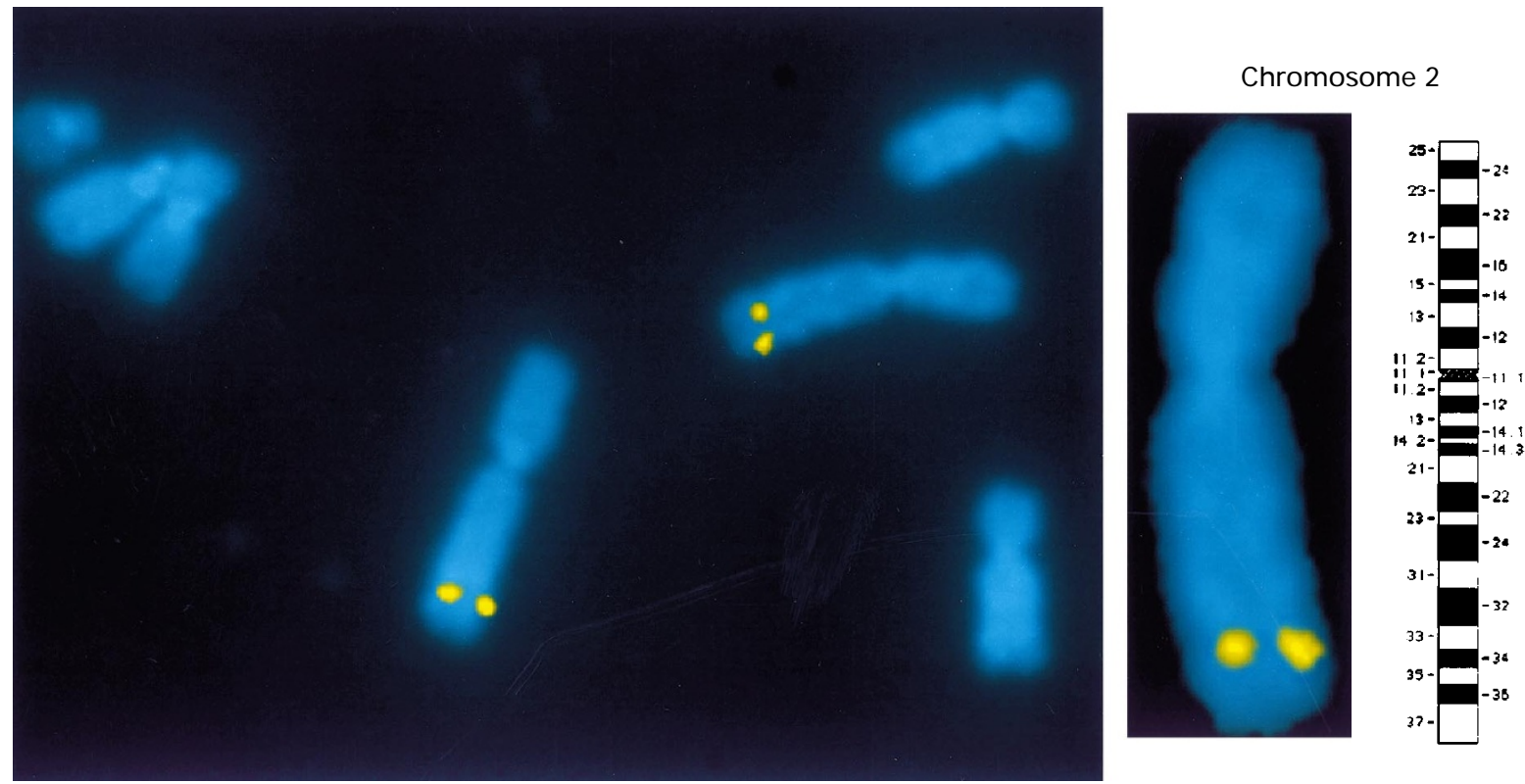

Figure 3 Chromosomal mapping of the Usurpin gene to 2q33-34. A genomic PAC clone was identified by screening a P1 artificial chromosome library using the Usurpin cDNA. The genomic insert was biotinylated and used to map the Usurpin gene by fluorescence in situ hybridization (FISH) with normal human lymphocyte chromosomes. FITC-avidin was used to visualize the Usurpin signal (yellow) on chromosomes that were DAPI counterstained (blue). Metaphase chromosomes accompanied by a schematic representation (right) depict the localization of the FISH signals at 2q33-34 

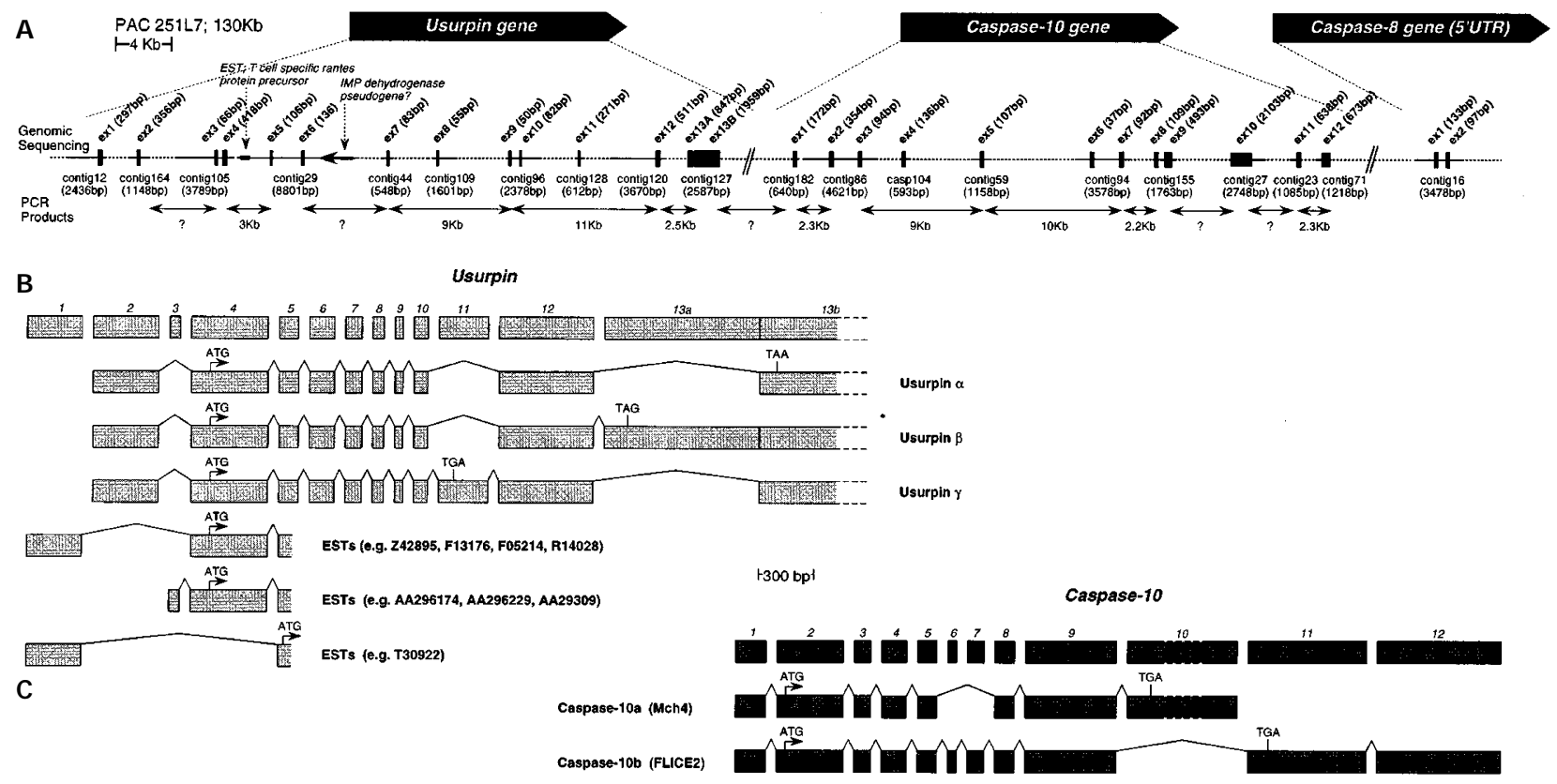

Figure 4 Genomic organization of the DED-Caspase gene cluster. (A) Schematic representation of the genomic organization of Usurpin, caspase-10, and the $5^{\prime}$ UTR region of the caspase- 8 gene, which all reside on a $130 \mathrm{~Kb}$ region covered by the PAC $251 \mathrm{~L} 7$ as shown. The contigs that contained the exonic sequences for the Usurpin, caspase-10 and caspase-8 genes were identified by comparing the CDNA sequences with the PAC genomic sequences produced by high-throughput PAC sequencing. These contigs are aligned along with the physical map of the PAC clone. Both Usurpin and caspase-10 genes are predicted to be approximately $40 \mathrm{~Kb}$ in size. The caspase-8 gene is also approximately $40 \mathrm{~Kb}$ in size (unpublished), therefore these three genes will fall within $<200 \mathrm{~Kb}$ of genomic DNA. (B) Schematic representation of the structure of the Usurpin gene and its isoforms, comprising a minimum of 13 exons within $40 \mathrm{~Kb}$ genomic DNA. Several isoforms for the Usurpin transcripts have thus far been identified resulting in at least three polypeptides. (C) Schematic representation of the structure of the caspase-10a (Mch4)/Caspase-10b (FLICE2) gene, comprising a minimum of 8 and 11 exons respectively

polypeptides $(52.6 \mathrm{kDa})$, on the other hand, could not be detected in any of the tissues tested.

\section{Modus Operandi: Usurpin binds pro-Caspase-8 and prevents its association with FADD/MORT1}

Two structural components within the Usurpin polypeptide suggest that it may function through heterologous protein : protein interactions with components of the CD95 (Fas/ APO-1) 'death-inducing signaling complex' (the 'DISC') (Medema et al, 1997). First, death effector domains (DEDs) have been shown to modulate intermolecular dimerization events through DED:DED associations. In the case of the CD95 (Fas/APO-1) system, the DEDs contained within the prodomain of pro-caspase- 8 bind to the DED contained within the FADD/MORT1 adapter protein and this facilitates the recruitment of pro-caspase-8 to the CD95 (Fas/APO-1) receptor complex where caspase-8 is subsequently activated and launches the cell death pathway. The two DEDs contained within Usurpin might also participate in these interactions. Secondly, caspases themselves homodimerize. This may in some cases be mediated by prodomains (e.g. ICE/ caspase-1) (Van Criekinge et al, 1996), but the catalytic subunits of the enzymes can also associate, as demonstrated by the three-dimensional arrangement of caspases- 1 and 3 (Rotonda et al, 1996; Walker et al, 1994; Wilson et al, 1994). In both cases, two large subunits and two small subunits are intimately associated in a compact tetramer comprised of two large subunit/small subunit heterodimers. This arrangement suggests that mature caspase tetramers arise from the association of two homologous caspase proenzymes. Heterologous association of different caspase family members has not been shown to occur in vivo, suggesting that stringent structural features disfavor non-homologous proenzyme interactions. It is possible, however, that highly related caspase-like polypeptides, such as Usurpin, sufficiently mimic these determinants enabling association with other proteins such as pro-caspase-8. These associations were examined using an in vitro binding assay where FLAG-epitope tagged recombinant Usurpin, or a prodomainless version ( $\Delta$ proUsurpin), was immuno-immobilized on agarose beads and used as bait to harvest $\left[{ }^{35} \mathrm{~S}\right]$ proteins generated by coupled in vitro transcription/translation (Figure 6a). Usurpin was able to homodimerize in vitro and this interaction occurred in both the presence and absence of the DED-containing prodomain (Figure 6a, first and second panels). Removal of the prodomain from the recombinant bait protein slightly decreased the efficiency of harvesting of $\left.{ }^{35} \mathrm{~S}\right]$ Usurpin but improved the efficiency of harvesting of $\left[{ }^{35} \mathrm{~S}\right] \Delta$ pro-Usurpin (lanes 3 versus 4). These results demonstrate that determinants from both the prodomain and the catalytically non-functional caspase component of Usurpin contribute to homodimerization, and that the caspase-like component, without the prodomain, is itself sufficient for homodimerization. 
Similar interactions were observed with the association of Usurpin and pro-caspase-8 (Figure 6a, third panel). Both full-length Usurpin and $\Delta$ pro-Usurpin could harvest $\left[{ }^{35}\right.$ S]pro-caspase-8, with the binding efficiency in the presence of the prodomain being marginally better in vitro than in the absence of the prodomain. This demonstrates that Usurpin can bind pro-caspase-8 in vitro, that this heterodimerization is most efficient with intact Usurpin containing both the prodomain and caspase-like components, and that the caspase-like domain of Usurpin is
A

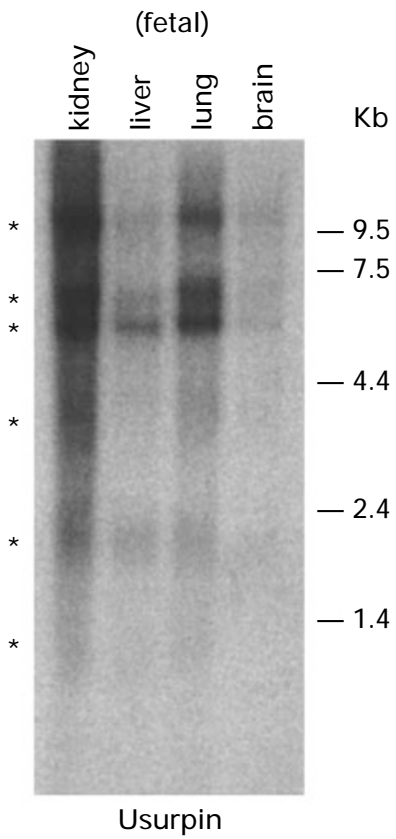

(adult)

heart

brain

placenta

lung

liver

skeletal muscle

kidney

pancreas

spleen

thymus

prostate

testis

uterus

small intestine

colon

leukocytes

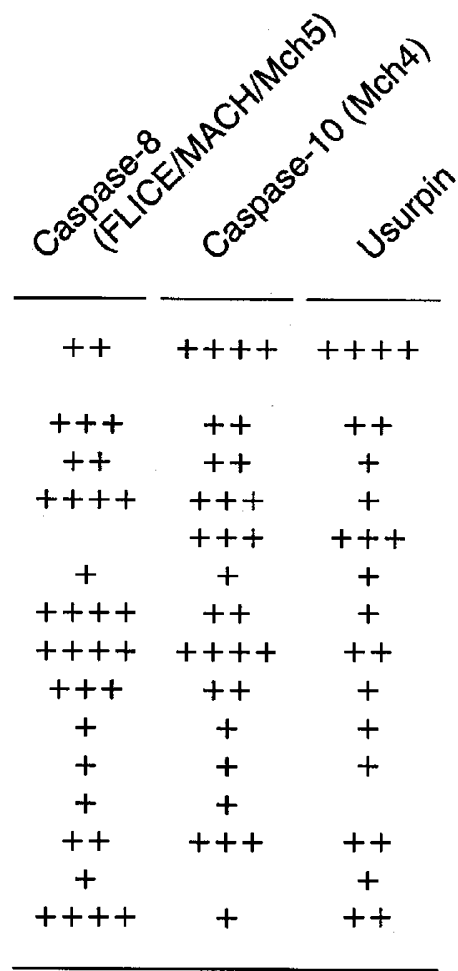

\section{B}

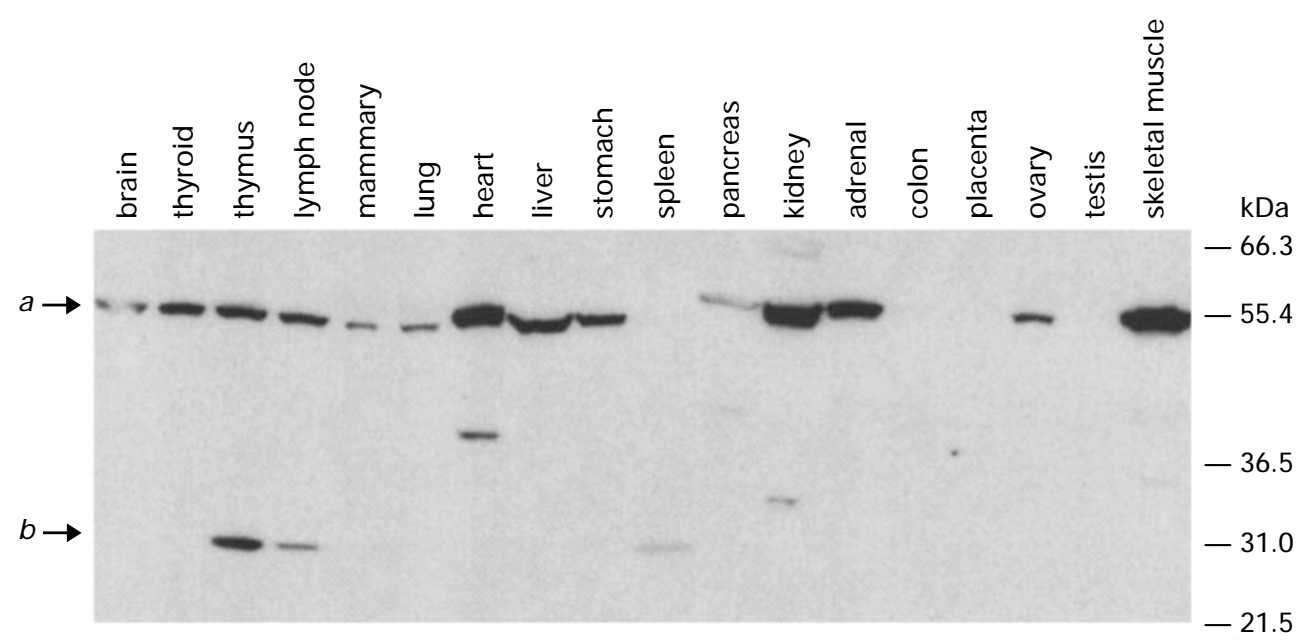

Figure 5 Human tissue distribution of Usurpin poly $(A)^{+}$RNA and protein. (A) Northern blot analysis. Human fetal multiple-tissue Northern blots were probed for the presence of Usurpin poly $(A)^{+}$RNA using a $\left[{ }^{32} \mathrm{P}\right]$ cDNA probe corresponding to bases 793-1947 (which encodes DED-B and both caspase-like subunits) of Usurpin- $\alpha$. RNA standards are indicated on the right of the resulting autoradiogram, and the predominant Usurpin bands are indicated by the $*$ symbol. Northern blots from adult tissues were analyzed in an identical manner (right side of panel A) and the relative intensity of the bands was estimated, with ++++ indicating the maximum intensity observed. No symbols indicates that Usurpin bands could not be observed. Similar estimates were made for caspase-8 and -10 based on published Northern blots from the same commercial source. (B) Western blot analysis. Fifty $\mu \mathrm{g}$ of total homogenate protein from the indicated human organs were resolved on $10 \%$ SDS-polyacrylamide gels, transferred to nitrocellulose by electroblotting then probed for the presence of Usurpin immunoreactivity using a rabbit polyclonal antibody raised against recombinant human $\triangle D E D-A$ Usurpin. The dominant band (indicated by a) corresponds in mass to the Usurpin- $\alpha$ isoform $(55.3 \mathrm{kDa})$ whereas a minor band of lower mass (indicated by $b$ ) migrates just below the predicted mass of the Usurpin- $\gamma$ isoform ( $33.3 \mathrm{kDa})$ 
A

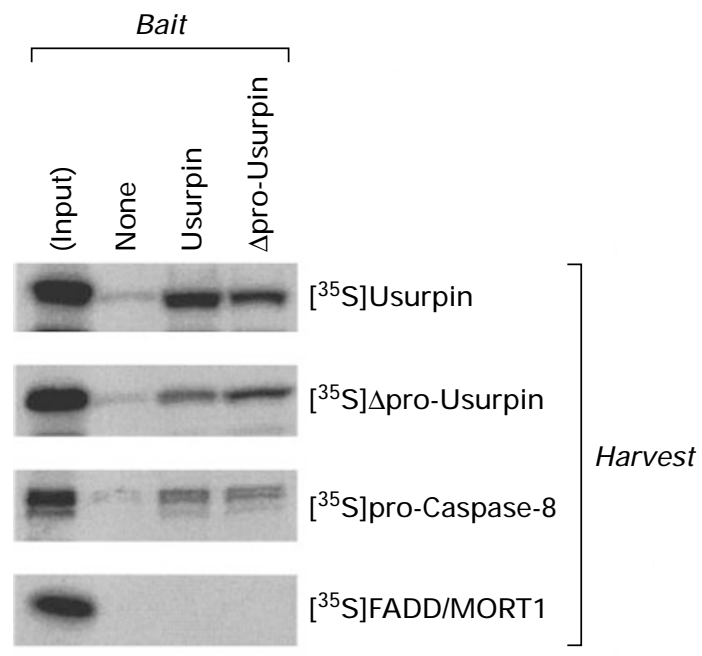

B
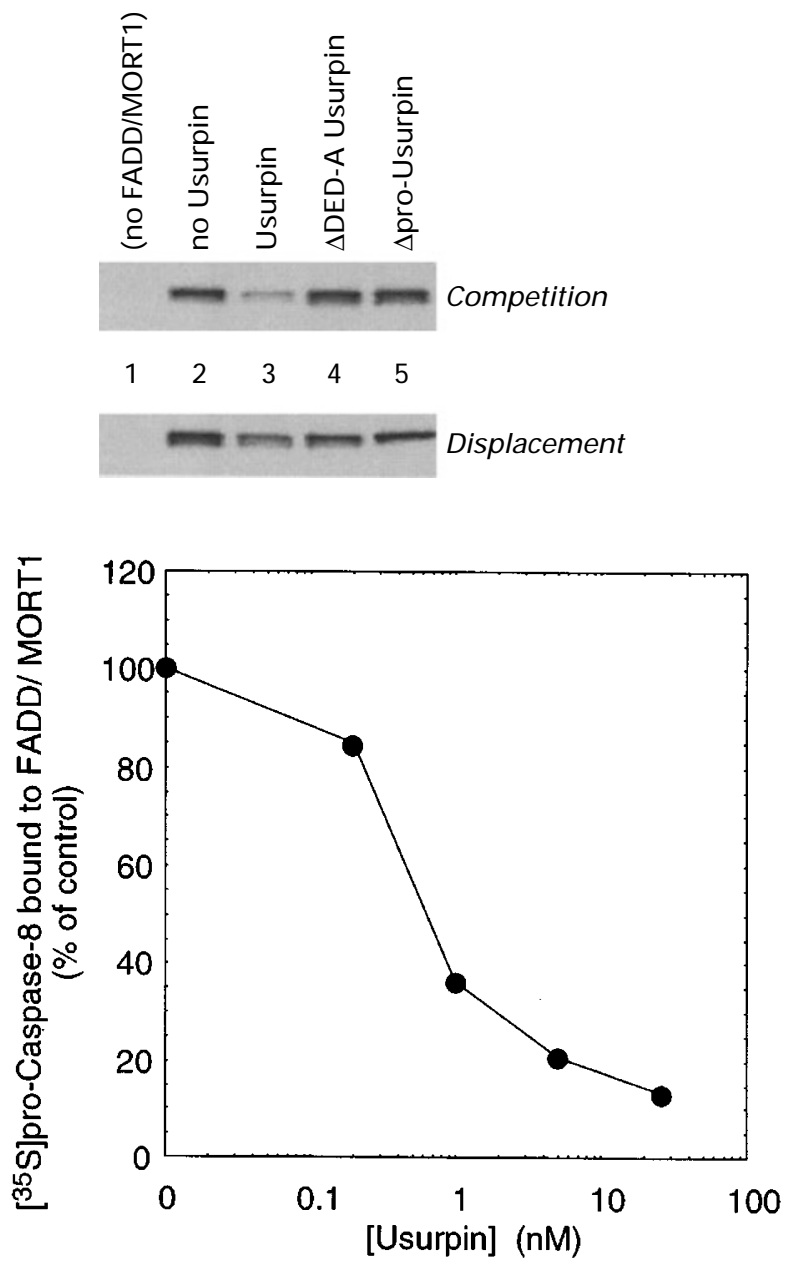

Figure 6 Usurpin heterodimerization with pro-Caspase-8 prevents proCaspase-8 association with FADD/MORT1. (A) Binding of $\left[{ }^{35} \mathrm{~S}\right]$ DEDcontaining polypeptides to immobilized Usurpin. Full length Usurpin (lanes 3 ) and a prodomainless construct ( $\Delta$ pro-Usurpin; lanes 4$)$ were $C$-terminal tagged with the FLAG epitope (DYKDDDDK), expressed in bacteria then immobilized on anti-FLAG agarose beads (the 'bait'). The beads were alone sufficient for heterodimerization with the caspase-8 proenzyme.

Despite the presence of two DEDs within the Usurpin prodomain, Usurpin did not interact with the FADD/MORT1 adapter protein in vitro (Figure 6a, bottom panel). This indicates, at least within the CD95 (Fas/APO-1) receptor system, that Usurpin interactions are confined to procaspase-8 but probably do not include FADD/MORT1.

Because of the ability of Usurpin to bind pro-caspase-8, but not FADD/MORT1, Usurpin is likely to interfere with pro-caspase-8 recruitment by FADD/MORT1 to the CD95 (Fas/APO-1) receptor complex. This was tested by determining whether Usurpin affected FADD/MORT1: procaspase-8 association in vitro (Figure 6b). StrepTag-FADD/ MORT1 was immobilized on streptavidin agarose then used to harvest $\left[{ }^{35}\right.$ S]pro-caspase-8 in the absence or presence of various Usurpin constructs. In a competition assay (Figure $6 \mathrm{~b}$, upper panel), Usurpin effectively inhibited the ability of FADD/MORT1 to harvest $\left[{ }^{35}\right.$ S]pro-caspase-8 $(83 \%$ inhibition, lane 3 versus $2 ; \mathrm{IC}_{50}$ value $=650 \mathrm{pM}$, titration depicted in graph) whereas neither Usurpin lacking the first DED ( $\triangle$ DED-A Usurpin, lane 4) nor prodomainless Usurpin ( $\Delta$ pro-Usurpin, lane 5 ) were able to. In a displacement assay, where the FADD/MORT1: $\left[{ }^{35}\right.$ S]pro-caspase-8 interaction was allowed to form prior to the addition of Usurpin (Figure $6 \mathrm{~b}$ lower panel), Usurpin was less effective at inhibiting their association $(60 \%$ inhibition; lane 3 versus

combined with reticulocyte lysates containing the indicated $\left[{ }^{35} \mathrm{~S}\right]$ proteins, which were generated by coupled in vitro transcription/translation, in a buffer containing $20 \mathrm{mM} \mathrm{Tris} / \mathrm{HCl}$ (pH7.5), $100 \mathrm{mM} \mathrm{NaCl}, 2 \mathrm{mM}$ EDTA, $0.1 \%(\mathrm{w} / \mathrm{v})$ Nonidet P-40, $2 \mathrm{mM}$ dithiothreitol, $0.05 \%$ (w/v) BSA plus $5 \%$ (v/v) glycerol and incubated for $2 \mathrm{~h}$. at $10^{\circ} \mathrm{C}$. The beads were washed five times as described in Methods then the harvested $\left[{ }^{35} \mathrm{~S}\right]$ proteins were eluted with SDS-containing sample buffer, resolved on SDS-polyacrylamide gels and visualized by fluorography. Lanes 2 are controls treated in an identical manner except that no Usurpin was present on the beads. (B) FADD/MORT1 recruitment of $\left[{ }^{35} \mathrm{~S}\right]$ pro-caspase-8 in the presence of Usurpin. FADD/MORT1 was C-terminal tagged with the StrepTag streptavidin recognition decapeptide (SAWRHPQFGG), expressed in bacteria then bound to streptavidin-agarose beads. Recombinant Usurpin (lanes 3), or versions lacking the first DED ( $\triangle D E D-A$ Usurpin; lanes 4 ) or the entire prodomain ( $\Delta$ pro-Usurpin; lanes 5 ), were also generated by expression in bacteria (as described in Methods). $\left[{ }^{35}\right.$ S]pro-Caspase-8 (MACH, FLICE, Mch5) was made by coupled in vitro transcription/translation in rabbit reticulocyte lysates. In the competition format (upper panel), $\left[{ }^{35} \mathrm{~S}\right]$ pro-caspase-8 and the indicated recombinant Usurpins ( $25 \mathrm{nM}$ for Usurpin (lanes 3), $70 \mathrm{nM}$ for $\triangle$ DED-A Usurpin (lanes 4), $150 \mathrm{nM}$ for $\Delta$ pro-Usurpin (lanes 5)) were pre-mixed for $15 \mathrm{~min}$ at $4^{\circ} \mathrm{C}$ (in buffer containing $50 \mathrm{mM} \mathrm{Tris} / \mathrm{HCl}$ (pH 8.0), $2 \mathrm{mM}$ EDTA) prior to the addition of immobilizedFADD/MORT1 beads. After further incubation for $2 \mathrm{~h}$ at $4^{\circ} \mathrm{C}$, the beads were washed three times then the harvested $\left[{ }^{35}\right.$ S]pro-caspase- 8 was eluted with $1 \mathrm{mM}$ d-biotin, resolved on SDS-polyacrylamide gels and visualized by fluorography. In the displacement format, $\left[{ }^{35}\right.$ S]pro-caspase-8 was pre-bound (for $15 \mathrm{~min}$ at $4^{\circ} \mathrm{C}$ ) to the immobilized-FADD/MORT1 beads prior to the addition of the indicated Usurpin constructs. After further incubation for $2 \mathrm{~h}$ at $4^{\circ} \mathrm{C}$, the amount of $\left[{ }^{35} \mathrm{~S}\right]$ pro-caspase-8 that remained bound to the FADD/ MORT1 beads was assessed as described for the competition format. Lanes 1 are controls with streptavidin-agarose beads that did not contain FADD/ MORT1 and lanes 2 are controls showing the binding of $\left[{ }^{35} \mathrm{~S}\right]$ pro-caspase- 8 to FADD/MORT1 in the absence of Usurpin. The graph shows the ability of varying concentrations of full-length Usurpin to prevent $\left[{ }^{35} \mathrm{~S}\right]$ pro-Caspase-8 (MACH, FLICE, Mch5) binding to immobilized FADD/MORT1 using the competition format described above (e.g. equivalent to lane 3 of the upper panel of B) 
2). Collectively, these experiments demonstrate that Usurpin precludes pro-caspase-8 association with the FADD/MORT1 adapter protein, but that once an interaction is formed between these polypeptides, it is relatively resistant to Usurpin interference.

\section{Usurpin attenuates cell death resulting from CD95 (Fas/APO-1) receptor ligation}

Jurkat $\mathrm{T}$ lymphocytes are a well established cell line that is responsive to Fas ligand-mediated apoptosis. Jurkats contain multiple caspase family members including the group III activator protease, caspase-8 (17 pM), the group II apoptosiseffector protease, caspase-3 (86 pM), as well as Usurpin (6 pM) (Figure 7a). When induced to undergo apoptosis by CD95 (Fas/APO-1) receptor ligation, all of the caspase-8 proenzyme was processed from its $55 \mathrm{kDa}$ (p55) precursor form (Figure 7a, left panel; concomitant appearance of the mature form ( $p 17$ ) was not detected by immunoblotting owing to putative high turnover of the mature form, a feature common to several caspases following activation). Similarly, more than $60 \%$ of the $32 \mathrm{kDa}$ caspase-3 proenzyme (p32) was converted to catalytically active mature forms (Figure 7a, middle panel; p20 and p17 being the large subunit with or without the 28 amino acid prodomain, respectively). The full length Usurpin- $\alpha$ isoform, however, was unaffected during apoptosis (Figure 7a, right panel, band a). In contrast, a faster-migrating Usurpin- $\gamma$ band was present in apoptotic extracts (band $b$ and $b^{\prime}$ putatively being Usurpin- $\gamma$ and its cleaved form, respectively). A similar faster-migrating Usurpin- $\gamma$ band was generated when healthy Jurkat cell extracts were incubated with granzyme B (Figure 7b). Based on fragment sizes, the cleavage site within the smaller Usurpin- $\gamma$ polypeptide was predicted to be $\operatorname{LITD}^{258} / \mathrm{C}^{259}$, a consensus site for group III caspases, including caspase-8, as well as for granzyme B (Thornberry et al, 1997). These experiments demonstrate that the endogenous levels of Usurpin- $\alpha$ in Jurkat cells (6 pM) are insufficient to block caspase- 8 activation and subsequent caspase- 3 mediated apoptosis. (This is consistent with the concentration of Usurpin required in vitro to inhibit pro-caspase-8 association with FADD/MORT1 $\left(\mathrm{IC}_{50}=650 \mathrm{pM}\right.$; see above and Figure 6b).) Furthermore, since Usurpin- $\alpha$ contains several excellent caspase consensus sites which do not become cleaved during apoptosis (e.g. LITD ${ }^{258} / \mathrm{C}^{259}$ at the prodomain/large subunit counterpart junction, and LEVD ${ }^{376} / \mathrm{G}^{377}$ at the large subunit/small subunit counterpart junction), it is possible that homodimerization masks them from caspase proteolysis. The shorter Usurpin- $\gamma$ isoform, which cannot benefit from homodimerization endowed by the caspase-like component
A

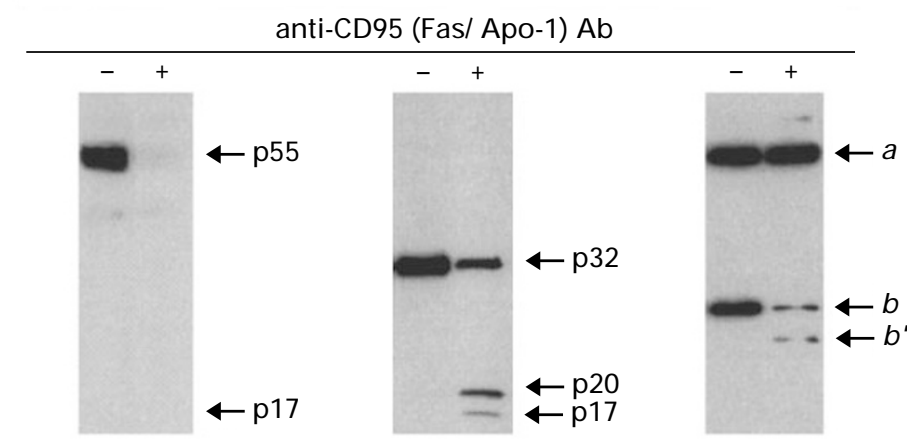

Caspase-8

$17 \mathrm{pM}$
Caspase-3

$86 \mathrm{pM}$
B

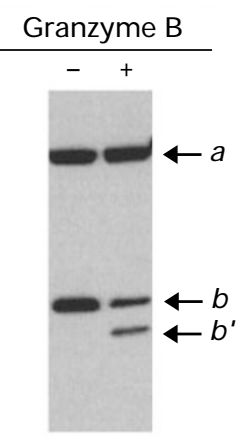

Usurpin

Figure 7 Resistance of Usurpin- $\alpha$ to proteolytic cleavage during apoptosis. (A) Human Jurkat cells in logarithmic growth were transferred to serum-free medium, cultured overnight then either treated $(+)$ or not $(-)$ with $1 \mu \mathrm{g} / \mathrm{ml}$ of anti-CD95 (Fas/APO-1) monoclonal antibody CH11 for an additional $2 \mathrm{~h}$. The cells (or apoptotic corpses) were harvested by centrifugation, lysed in buffer containing $0.1 \%$ (w/v) CHAPS, and the resulting cytosol fraction ( $50 \mu \mathrm{g}$ protein) resolved on $10-20 \%$ SDS-polyacrylamide gradient gels then electroblotted to nitrocellulose membranes for Western blot/ECL immunodetection. Polyclonal antibodies raised in rabbits against the recombinant large subunit of human caspase-8 (left panel), the recombinant large subunit of human caspase-3 (center panel) or recombinant human Usurpin (lacking the first DED; $\triangle \mathrm{DED}-\mathrm{A}$ Usurpin) (right panel) were used as primary antibodies as indicated. For the caspase-8 immunoblot, p55 indicates the $55 \mathrm{kDa}$ proenzyme and $\mathrm{p} 17$ indicates the position that the mature large subunit migrates (not detected in these blots). For the caspase- 3 immunoblot, p32 indicates the migration of the $32 \mathrm{kDa}$ proenzyme and p20, p17 are the partially mature and fully mature large subunit, respectively. For the Usurpin immunoblot, a indicates the migration of the Usurpin- $\alpha$ isoform whereas $b$ and $b^{\prime}$ denote the intact and cleaved forms of what appears to be the Usurpin- $\gamma$ isoform. The endogenous levels of pro-caspases- 8 and -3 as well as Usurpin- $\alpha$ in untreated, healthy Jurkat cells was estimated by quantitative Western immunoblot analysis. Known quantities of recombinant protein standards (caspase-8, -3 or Usurpin) were resolved on SDS-polyacrylamide gels with whole cell lysates derived from known numbers of cultured Jurkat cells. The immunoblot signal from the standards and the cell lysates was quantified by laser densitometry and used to calculate the amount of the three polypeptides present in the cells. The concentrations were calculated with the assumption that a) the average Jurkat cell volume was $0.5 \mathrm{nl}$, and $\mathrm{b}$ ) that the proteins were evenly distributed throughout the cells. (B) Usurpin cleavage by CTL-derived granzyme B. Cytosol fractions (50 $\mu \mathrm{g}$ protein) were isolated from untreated, non-apoptotic Jurkat cells then incubated with (+) or without (-) purified human granzyme B (67 ng in $25 \mu \mathrm{l})$ for $1 \mathrm{~h}$ at $37^{\circ} \mathrm{C}$. The samples were resolved on SDS-polyacrylamide gels and immunoblotted as described for panel A using anti-Usurpin antibody 
of Usurpin- $\alpha$, is probably monomeric in Jurkat cells and thus susceptible to cleavage.

Despite the presence of Usurpin (albeit at lower molar concentration versus pro-caspase-8), Jurkat cells are clearly sensitive to CD95 (Fas/APO-1) -mediated cell death. To determine whether elevated levels of Usurpin would favor Usurpin heterodimerization with pro-caspase-8 (as demonstrated above in vitro) and prevent CD95 (Fas/ APO-1)-mediated cell death, Usurpin was transfected into healthy Jurkat cells by electroporation then treated with the CD95 cross-linking antibody, CH11 (Figure 8a). Cells harboring Usurpin (indicated by co-transfection with Aequorea victoria green fluorescent protein) were substantially resistant to CD95 ligation-induced apoptosis. In contrast, Usurpin transfected cells remained susceptible to TNF $\alpha$-induced cell death (Figure $8 b$ ). Similar results were observed when apoptosis was induced by either caspase-8 or FADD/MORT1 overexpression followed by CD95 (Fas/

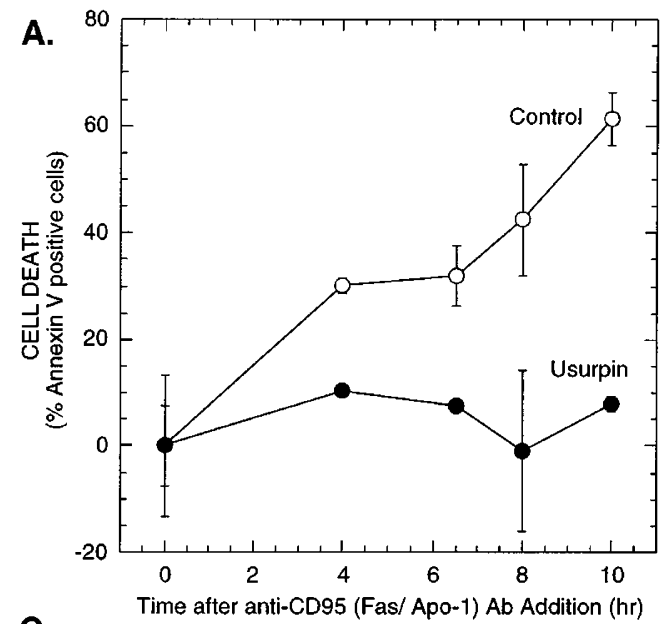

c.

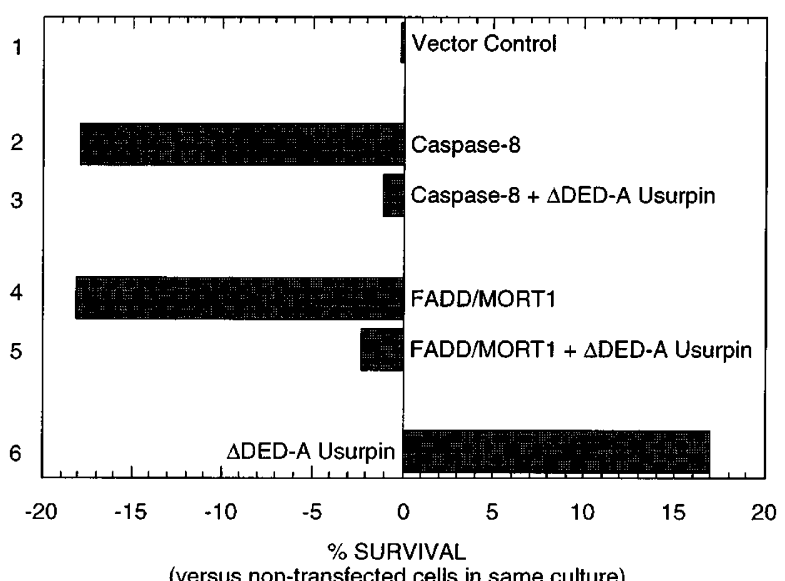

B.

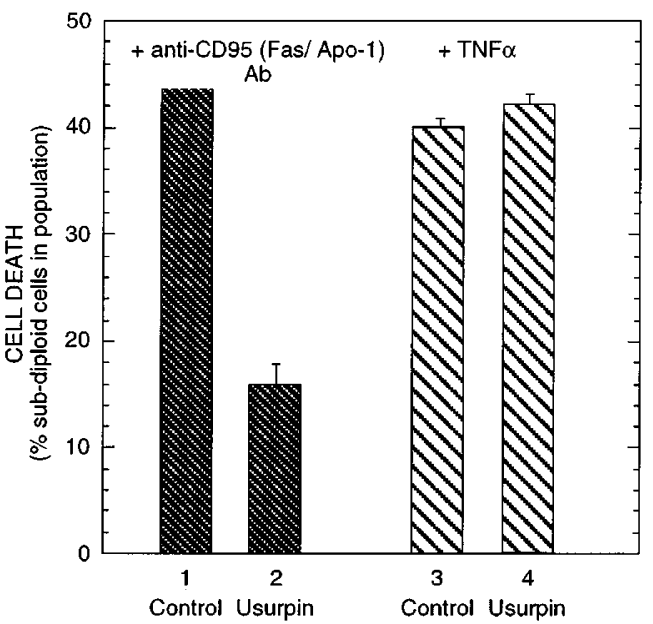

D.

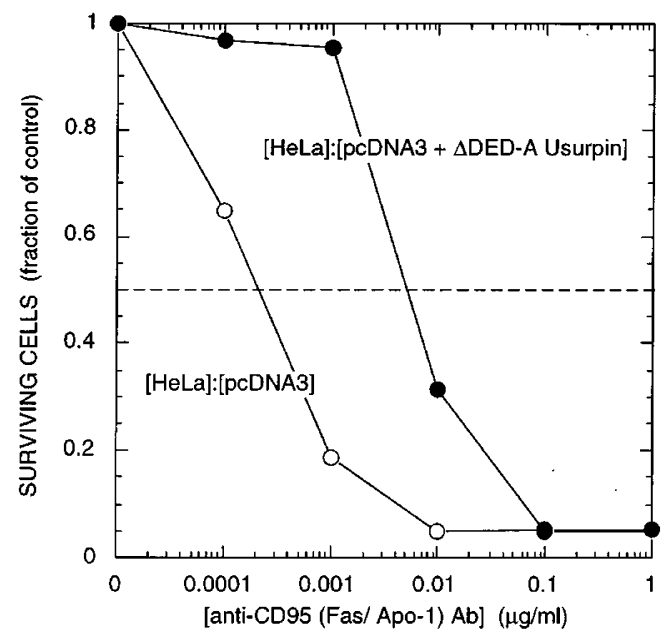

Figure 8 Effect of Usurpin on apoptosis. (A) Jurkat cells were co-transfected by electroporation with pcDNA3: GFP plus the control vector pcDNA3 (open symbols) or with pcDNA3:GFP plus pcDNA3 containing Usurpin (solid symbols). Twelve hours after transfection, the cells were re-isolated and subjected to treatment with anti CD95 (Fas/APO-1) monoclonal antibody $\mathrm{CH} 11(0.5 \mu \mathrm{g} / \mathrm{ml})$ for the indicated times. Cell death was determined by surface PS (phosphatidylserine) exposure as measured by the binding of biotinylated Annexin V and visualization with streptavidin PE by Facs analysis. Data are expressed as the percentage of the transfected cells (GFP positive; approx. 45\%) that were also Annexin V positive. (B) Jurkat cells were co-transfected by electroporation with pcDNA3: GFP plus the control vector pcDNA3 (control) or with pcDNA3: GFP plus pcDNA3 containing Usurpin (Usurpin). Twelve hours after transfection, the cells were re-isolated and subjected to treatment with anti CD95 (Fas/APO-1) monoclonal antibody $\mathrm{CH} 11(1.0 \mu \mathrm{g} / \mathrm{ml}$ ) for $15 \mathrm{~h}$ (columns $1 \mathrm{and} 2)$ or with recombinant TNF $\alpha(125 \mathrm{ng} / \mathrm{ml})$ for $48 \mathrm{~h}$ (columns 3 and 4$)$. Cell death was measured by the degree of DNA fragmentation which was assessed by propidium iodide staining of trypsin-permeabilized cells followed by Facs analysis. (C) Jurkat cells were co-transfected by electroporation with pcDNA3: GFP plus the indicated expression constructs in pcDNA3. Twelve hours after transfection, the cells were re-isolated and the transfection efficiency (GFP positive) was determined by Facs analysis. The cell cultures were then treated with anti CD95 (Fas/APO-1) monoclonal antibody $\mathrm{CH} 11(0.5 \mu \mathrm{g} / \mathrm{ml})$ for $72 \mathrm{~h}$ after which the number of viable transfected cells (GFP positive, propidium iodide negative) versus the number of viable non-transfected cells in the same culture dish (GFP negative, propidium iodide negative) were determined by Facs analysis. The percentage of the transfected cells that remained viable versus the non-transfected cells which remained viable is shown. (D) Stable HeLa cell lines containing either vector alone (open symbols) or vector containing Usurpin lacking the first DED ( $\triangle D E D-A$ Usurpin; solid symbols) were generated following calcium phosphate transfection and continuous selection for four weeks with $0.4 \mathrm{mg} / \mathrm{ml} \mathrm{G} 418$. The cells were then treated with the indicated concentrations of anti CD95 (Fas/APO-1) monoclonal antibody $\mathrm{CH} 11$ for $16 \mathrm{~h}$ and survival was measured by the retention of activity that could convert thiazolyl blue tetrazolium Br to the corresponding formazan. Data are presented as a percentage of controls cells that did not receive the antibody 
APO-1)- ligation (Figure 8c). In these cases, the presence of a Usurpin construct lacking the first 'death effector domain' ( $\triangle \mathrm{DED}-\mathrm{A}$ Usurpin) was still sufficient to afford protection against cell death initiated by these proteins. Although the presence of Usurpin DED-A appears to be important for preventing pro-caspase-8 recruitment to FADD/MORT1 in vitro (as described above in Figure 6b), $\triangle \mathrm{DED}-\mathrm{A}$ Usurpin was still able to impede the activation of caspase-8 and resulting cell death. This was also observed in a stable HeLa cell line bearing $\triangle D E D-A$ Usurpin (Figure 8d) which was also resistant to cell death following CD95 (Fas/APO-1) ligation.

Collectively, these results demonstrate that Usurpin is able to attenuate cell death mediated by caspase- 8 activation, such as that which normally occurs following ligation of CD95 (Fas/APO-1). The molar ratio of Usurpin versus that of caspase-8 proenzyme probably plays a critical role in determining whether Usurpin homodimerization is favored and caspase- 8 activation can occur unabated, or whether sufficient Usurpin is present to heterodimerize with pro-caspase- 8 and preclude both its recruitment to the CD95 (Fas/APO-1) receptor complex and its autolytic activation (Figure 9).

\section{Usurpin deficit in cardiac myocytes undergoing apoptosis following ischemia/reperfusion injury in vivo}

Owing to the prominence of Usurpin in cardiac tissue and the ability of Usurpin to attenuate apoptotic cell death, its distribution was examined in rat heart before and after ischemia/reperfusion injury which has recently been shown to result in cardiac myocyte apoptosis (Gottlieb et al, 1994; Kajstura et al, 1996; Sharov et al, 1996) and concomitant regional up-regulation of active caspase-3 (apopain, CPP32, Yama) expression levels (Black, S.C. et al, unpublished observations). Usurpin (represented by the red fluorescent signal in Figure 10a) was present in the non-ischemic,

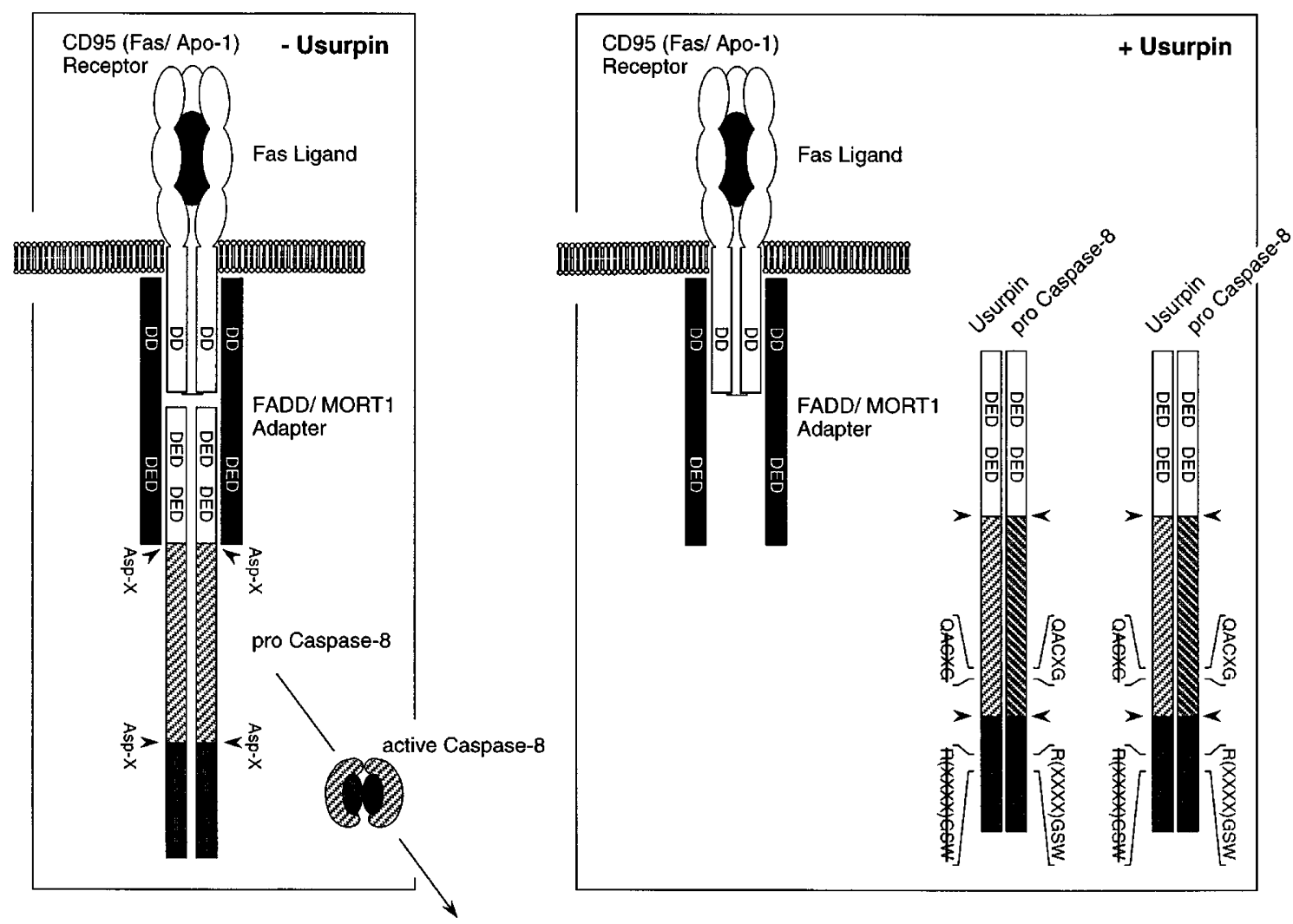

Apoptosis

Figure 9 Model for Usurpin-mediated attenuation of cell death following CD95 (Fas/APO-1) receptor ligation. The trimeric Fas ligand binds to its receptor resulting in oligomerization at the plasma membrane and recruitment of the FADD/MORT1 adapter protein. In the absence of Usurpin (left panel), FADD/MORT1 in turn recruits the caspase-8 proenzyme to form a 'death-inducing signaling complex' (DISC). The accumulation of multiple pro-caspase-8 polypeptides at a common site enables enzyme autoactivation, presumably through proenzyme interdigitation and intermolecular proteolysis. The resulting mature caspase-8 becomes liberated from the receptor complex owing to removal of the prodomain which otherwise links it to FADD/MORT1 via DED:DED interactions. Mature caspase-8 then proteolytically activates effector caspases, such as caspase-3, which subsequently cleave key cellular proteins that collectively manifest the apoptotic phenotype. In the presence of Usurpin (right panel), pro-caspase-8 is unavailable for recruitment by FADD/MORT1 due to heterodimerization with the catalytically nonfunctional Usurpin polypeptide. Pro-caspase-8 is precluded from homodimerization and concomitant intermolecular proteolysis and therefore cannot launch an apoptotic response 
control region of the heart, while there was limited Usurpin immunoreactivity in the ischemic and reperfused region of the heart. Usurpin immunoreactivity was uniformly distributed in all non-ischemic regions of the rat heart, including the right ventricular free wall and the interventricular septal region of

\section{a}

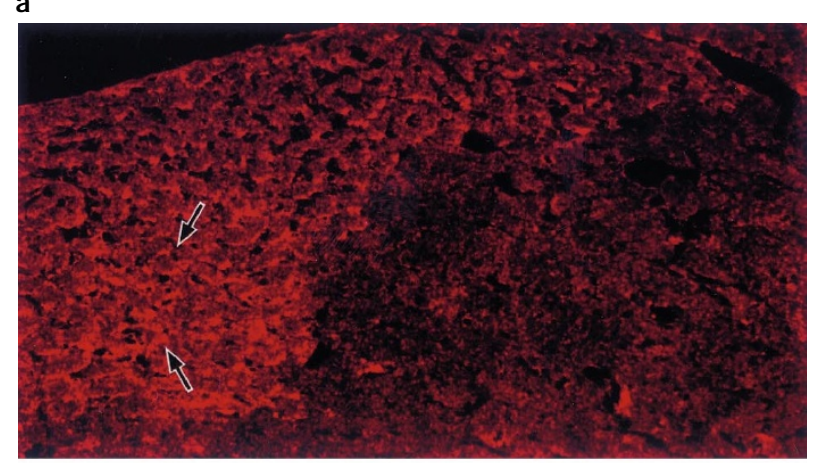

b

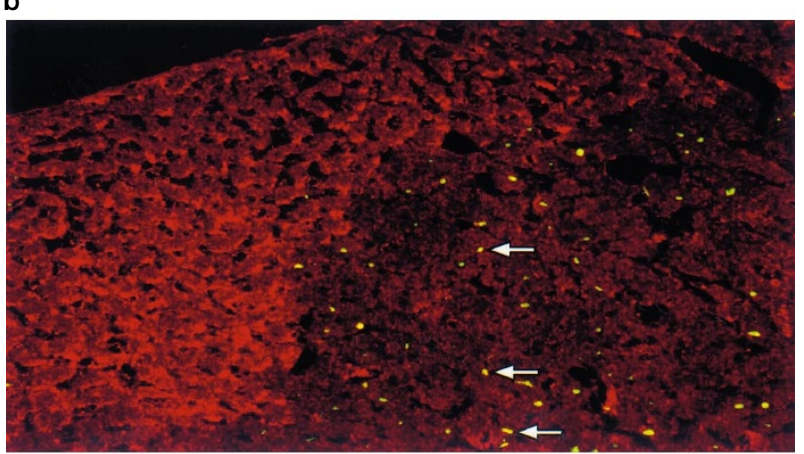

c

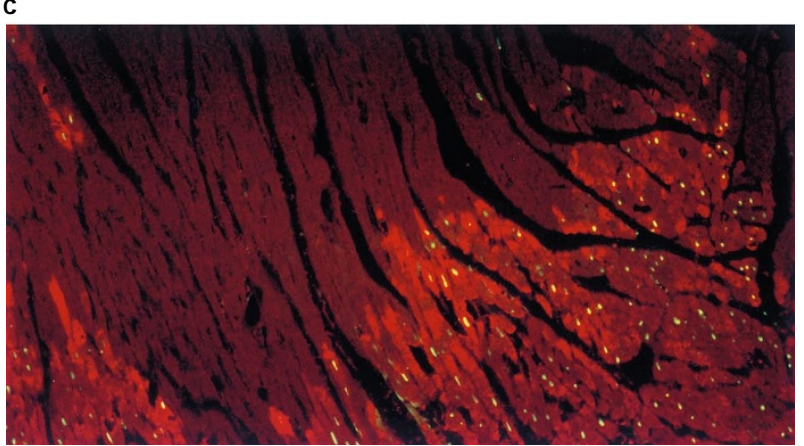

Figure 10 Presence of Usurpin in cardiac myocytes, except for regions undergoing apoptotic cell death following ischemia/reperfusion injury, and recipricol expression of active Caspase-3. (A) Localization of Usurpin in rat heart and (B) localization of Usurpin relative to apoptotic myocyte nuclei. The image is from a section of border region between control, non-ischemic left ventricle (upper left portion of panel) and a region of the left ventricle that was ischemic for $45 \mathrm{~min}$ and reperfused for three hours (lower right). In panel $\mathbf{A}$, Usurpin-positive myocytes are represented by the red fluorescent signal (black arrows). The Usurpin-positive immunoreactivity was in non-ischemic, control left ventricle (as well as the entire contra-lateral ventricle; not shown), whereas the region that was Usurpin negative (darker non-fluorescent region) was within the ischemic and reperfused ventricle. In panel B, TUNEL-positive myocyte nuclei are indicated by the bright yellow/green signal (white arrows) and do not co-localize with Usurpin-positive cells. Panel $\mathbf{C}$ is similar to panel $\mathbf{B}$, except that the primary antibody was raised against $\mathrm{X}$-ray crystallographic-grade active caspase- 3 tetramer. The width of each panel corresponds to $0.2 \mathrm{~mm}$ the left ventricle (data not shown). To determine the possible relationship between ischemia/reperfusion-induced apoptosis and cardiac Usurpin distribution, co-localization studies with the Usurpin antibody and TUNEL positive nuclei were performed (Figure 10b). Myocytes that were TUNEL positive, and thus presenting nuclear changes associated with the apoptotic phenotype, were evident in the region of the infarcted tissue where there was a clear attenuation in the Usurpin signal. In contrast, there were no TUNEL-positive myocyte nuclei in the non-ischemic right ventricle and the interventricular septal region where Usurpin immunoreactivity was high. The distribution of Usurpin immunoreactivity was the reciprocal of that of the apoptosis effector protease, caspase-3, which was abundant in the TUNEL-positive infarcted tissue and low in unaffected regions of the heart (Figure 10c). The loss of Usurpin immunoreactivity in cardiac myocytes undergoing apoptotic cell death following ischemia/reperfusion injury was confirmed by Western blot analysis following micro-dissection of healthy versus infarcted tissue (Figure 11). As observed in human cardiac tissue (Figure $5 b$ ), the Usurpin- $\alpha$ isoform was the predominant Usurpin species in rat heart (Figure 11). Following the ischemia/reperfusion episode, this band was substantially reduced ( $<25 \%$ of control values) in the affected area of the heart where prominent apoptosis was occurring. Collectively these data suggest that the vulnerability of cardiac myocytes to apoptotic cell death following ischemia/reperfusion injury may result from the simultaneous gain of the pro-apoptotic protease, caspase-3, and loss of the protective contribution of Usurpin.

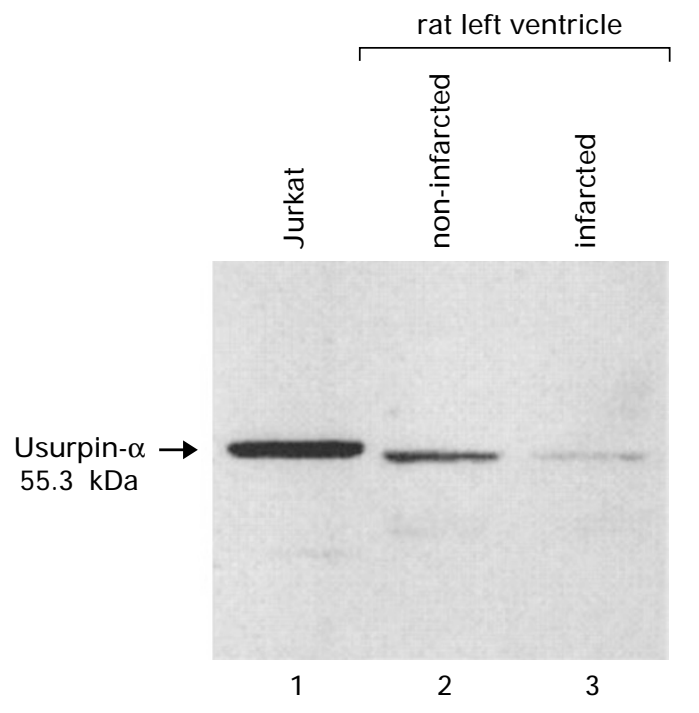

Figure 11 Loss of Usurpin- $\alpha$ from infarcted cardiac tissue following ischemia/ reperfusion injury. Following regional ischemia/reperfusion injury, infarcted and non-infarcted regions of the left ventricle were identified by triphenyltetrazolium chloride (TTC) viability staining, excised by micro-dissection and the protein constituents extracted and resolved by SDS/PAGE. Identical quantities of protein from Jurkat cells (lane 1), non-infarcted left ventricular tissue (lane 2) and infarcted left ventricular tissue (lane 3 ) were used. Overall protein banding patterns were indistinguishable between the two regions (not shown). Usurpin polypeptides were identified by Western blotting followed by ECL immunodetection using a rabbit polyclonal antibody raised against human Usurpin 


\section{Discussion}

An emerging theme in the conversion of catalytically dormant caspase proenzymes to their functionally mature counterparts is a mechanism of auto-activation which is initiated by 'facilitated' proenzyme dimerization. In this model, the driving force for protease activation would be the dimerization of caspase proenzymes. This hypothesis is supported by several lines of experimental and physical evidence (reviewed in Nicholson and Thornberry, 1997). First, when caspase proenzymes are generated at sufficiently high concentrations by overexpression in heterologous systems, such as bacteria, they become proteolytically activated. That this process is autolytic has been confirmed with active site mutants which do not become processed under identical conditions. In the few cases that have been examined, the Asp-X maturation sites are the same as those found in the purified active enzymes from human cells. Similar autoactivation events can be re-constituted in vitro when caspase proenzymes (e.g. caspase-1 and -3) are concentrated by ultrafiltration or by chromatographic accumulation on anionexchange beads. Collectively, these observations demonstrate that proenzyme aggregation is sufficient to initiate caspase self-maturation and that the resulting enzyme is indistinguishable from the enzyme in vivo.

The most compelling evidence linking proenzyme dimerization (or multimerization) events with caspase activation comes from the CD95 (Fas/APO-1) system itself where ligand-mediated receptor oligomerization at the cell surface leads to the recruitment of multiple caspase-8 proenzymes to a common site (Boldin et al, 1996; Medema et al, 1997; Muzio et al, 1996). The resulting activation of pro-caspase-8 presumably occurs through intermolecular autoproteolysis as it does in vitro. Although other possibilities have not yet been excluded (e.g. co-recruitment of as-yet-unidentified activation proteases), this appears to be a reasonably likely interpretation of the sequence of events that occur in response to receptor ligation. Supporting evidence that this mechanism is feasible comes from fusion constructs in which the prodomain of caspase-8 was replaced with the FK-506 binding protein (FK506-BP), a protein that dimerizes in the presence of the immunosupressant FK-506. Cells transfected with this chimera were induced to undergo apoptosis when the protein was dimerized with a cell permeable FK506 dimer (FK-1012) (VM Dixit, personal communication).

A third line of evidence indicating the importance of caspase proenzyme dimerization in protease maturation is suggested by the physical arrangement of subunits in the caspase-1 and -3 three-dimensional structures (Rotonda et al, 1996; Walker et al, 1994; Wilson et al, 1994). Both enzymes exist as (large subunit/small subunit) $)_{2}$ tetramers and the orientation of each functional large subunit/small subunit heterodimer is consistent with them originating from separate polypeptides following the interdigitation of two homologous proenzymes. In this model, the catalytic activity of both enzymes involved in the interdigitated proenzyme dimer would be necessary for the generation of functional, mature caspases. If Usurpin were interdigitated with pro-caspase-8, the large subunit of caspase-8 would be paired with the small subunit of Usurpin, and vice versa, and a proteolytically-competent caspase could not arise from this hybrid.

Together, these features provide an attractive model for the modulation of caspase activation and also account for the attenuation of caspase-8 activation in the CD-95 (Fas/ APO-1) system. The sensitivity of cells bearing components of this receptor system can be regulated at several levels including, now, the relative abundance of Usurpin. Usurpin heterodimerizes with pro-caspase- 8 and prevents (i) its recruitment via FADD/MORT1 to the CD-95 (Fas/APO-1) receptor complex, (ii) the homodimerization of pro-caspase8 which would otherwise lead to autoactivation, and (iii) the activation of caspase- 8 within the putative interdigitated Usurpin/pro-caspase-8 heterodimer. The presence of Usurpin thus confers resistance to Fas-ligand cell death, a process which plays an important role in memory $\mathrm{T}$ cell persistence as well as resistance of tumors to CTL killing and other key physiological processes which rely on procaspase-8 dimerization to launch a cell death response.

The potential importance of this molecule in vivo is exemplified by its presence in cardiac tissue that is protected from apoptosis following ischemia/reperfusion injury and its absence from areas where prominent apoptotic cell death occurs. Furthermore, it suggests that Usurpin levels are rapidly modulated in response to stresses which ultimately provoke apoptotic cell death. In cardiac infarcts we have observed that regions undergoing prominent apoptosis are highly positive for the active form of caspase-3 (e.g. the immunohistochemical staining of TUNEL-positive tissue observed in Figure 10c when using an antibody that preferentially recognizes the active form of caspase-3 (MF397)). Total caspase-3 levels (proenzyme plus mature active form) were unaffected by ischemia/ reperfusion injury (not shown) demonstrating that a constant caspase- 3 pool is converted from its dormant proenzyme form to its active mature form in infarcted regions of the heart, without a net gain or loss of total caspase-3 polypeptide content. Usurpin, on the other hand, appears to be rapidly down-regulated following an insult such as ischemia/reperfusion. Whether this is due to elevated proteolytic degradation, or whether Usurpin is subject to rapid turnover under normal conditions and biosynthetic replacement is attenuated during cardiac injury, is not yet clear. This merits further investigation to resolve how Usurpin levels may be regulated in vivo and how this in turn contributes to the resistance or susceptibility of cells to apoptosis in both physiological and disease states.

\section{Materials and methods}

\section{Cloning of Usurpin}

Unless otherwise indicated, all nucleotide numbering refers to the Usurpin- $\alpha$ isoform, GenBank accession AF015450. A partial cDNA clone for Usurpin was identified within the Merck/Washington University EST (expressed sequence tag) library (IMAGE Consortium no. 427786, zh82c06). The clone began (5') at bp 1042 (accession AA001257) and extended into the Usurpin $3^{\prime}$ UTR. The EST clone was 
retrieved, entirely sequenced then used to design primers for $5^{\prime}$ RACE amplification. Extended cDNA clones were generated from brain, liver, spleen and placenta Marathon-ready cDNA templates (Clontech) using the reverse-complement of bp 1093-1114 (5'-GGA GCC TGA AGT TAT TTG AAG G-3') plus the AP1 primer (Clontech) in the primary PCR amplification reaction with Taq polymerase (Boehringer Mannheim), then the reverse-complement of bp 1067-1090 (5'-CCT TGA GAC TCT TTT GGA TTG CTG-3') plus the AP2 primer in the nested secondary reaction. Amplification products were ligated into the vector pCR 2.1 by TA cloning (Invitrogen) then sequenced. The longest $5^{\prime}$ RACE products extended to bp 735, which was sufficient to encode $\triangle$ DED-A Usurpin (using $\mathrm{Met}^{97}$ as a start codon) but did not include the first 'death-effector domain'. Since the initial EST clone lacked key determinants that were known to be necessary for caspase catalytic activity, $3^{\prime}$ RACE amplification was performed to attempt to recover functionally-competent splice variants if they were to exist. The primary PCR amplification of the same Marathon-ready CDNAs as described above was performed using the primer 5'-CAA GTT ACA GGA ATG TTC TCC AAG-3' (bp 1043-1066) plus AP1, then the nested primer 5'-CAG CAA TCC AAA AGA GTC TCA AG-3' (bp 10671089) plus AP2 in the secondary reaction. Amplification products were ligated into the vector PCR 2.1 by TA cloning (Invitrogen) then sequenced, but no clones were revealed containing putatively functional caspase sequences. Full length cDNA clones of Usurpin (Usurpin- $\alpha$ ) and splice variants (Usurpin- $\beta$ and $-\gamma$ ) were identified by screening a human fetal kidney, lambda gt $11 \mathrm{cDNA}$ library (Clontech $5^{\prime}$ StretchPlus) on nylon membranes (Colony/Plaque Screen Hybridization membranes, NEN). The probe for library screening was generated by reverse-transcriptase PCR (corresponding to bp 792-1947 which encodes Met ${ }^{97}-\mathrm{Thr}^{480}$ of Usurpin- $\alpha$ ) and was radiolabeled using $\left[\alpha^{32} \mathrm{P}\right] \mathrm{dATP}$ (RediPrime, Amersham). Hybridization was conducted overnight at $65^{\circ} \mathrm{C}$ in ExpressHyb solution (Clontech). Positive clones, identified by autoradiography after multiple rounds of dilution subcloning, were sequenced by PCR amplification of the phage inserts followed by direct DNA sequencing of the amplification products. Multiple clones of the three splice variants described herein were identified by this procedure (GenBank accession numbers AF015450 (Usurpin- $\alpha$ ), AF015451 (Usurpin- $\beta$ ) and AF015452 (Usurpin- $\gamma)$ ). The absence of a splice variant that could encode a caspase with functional substrate binding and catalytic determinants was verified by sequencing of a genomic Usurpin clone as described below.

\section{Isolation of PAC clones, genomic DNA sequencing and analysis of genomic organization}

To obtain genomic clones containing the Usurpin gene, a PAC DNA library (loannou et al, 1994) was screened with a partial Usurpin cDNA clone as a probe ( $\triangle D E D-A$ Usurpin). PAC DNA was extracted from all positive clones by using a standard alkaline-SDS or Qiagen plasmid extraction kit. For DNA sequencing, a sublibrary was first constructed from the PAC DNA (Rowen and Koop, 1994). In brief, the PAC DNA was isolated and randomly sheared by nebulization. The sheared DNA was then size fractionated by agarose gel electrophoresis and fragments above $2 \mathrm{~Kb}$ were collected, treated with Mung Bean nuclease, followed by T4 DNA polymerase and Klenow enzyme to ensure blunt-ends, and cloned into Smal-cut M13mp19. Random clones were sequenced with an $A B I 377$ sequencer and fluorescently labled primers $(A B I)$. DNAStar software for Macintosh computers was used for gel trace analysis and contig assembly. All DNA sequences were examined against available public databases primarily using BLASTn with RepeatMaster (University of Washington) through the BCM (Baylor College of
Medicine) Search Launcher. To define the exon-intron boundaries for the DED-caspase gene family, cDNA sequence data for Usurpin, caspase-10 and caspase-8 cDNAs obtained in this study and/or GenBank database submissions were compared with those of the PAC clone $251 \mathrm{~L} 7$ using various alignment programs from DNAStar, BLAST and GeneWorks Version 2.5 (IntelliGenetics). In brief, ninety contig DNA sequences produced by high thoughput sequencing of the PAC 251L7 DNA were searched against the cDNA sequence databases which identified the contigs that contained part of the exonic sequences for the DED-caspase genes. To ensure the positions of the exon/intron boundaries, a pair-wise sequence alignment was carried out using the GeneWorks program. The boundary junctions were determined by the sequences that conformed to the GT/AG intron/exon boundary rule. To predict the gene size for each DED-caspase gene, the regions between exons were amplified by using an Expand Long Template PCR system (Boehringer Mannheim). The physical map of the PAC 251L7 was then generated by assembling the contigs based on the contig size and the size of the PCR products that contained intronic DNA.

\section{Usurpin engineering and expression}

All variants of Usurpin were engineered by PCR-directed template modification using appropriate full-length clones as templates and $P$ Wo polymerase (Boehringer Mannheim) for the amplification reaction. Once ligated into appropriate vectors, all clones were fully sequenced to ensure that no errors were introduced by the PCR reaction. Clone designations below are in the following format: [construct]:[vector]: [insert site] : [sense orientation] : [identifier].

Constructs for in vitro transcription/translation: Full length Usurpin, $\triangle$ DED-A Usurpin and $\Delta$ pro-Usurpin fragments were generated using synthetic oligonucleotide primers containing flanking, nested restriction sites suitable for ligation into various commercial vectors. All three clones were made as $\mathrm{Xbal}-\mathrm{Xhol}-\mathrm{Ncol}$-(Usurpin construct)-Ncol$X$ hol-Xbal fragments that were subsequently purified from preparative agarose gels, trimmed with $X b a l$ (Boehringer Mannheim) then ligated into the $X b a l$ site of pBluescript II SK+ and transformed into $E$. coli XL2-blue cells (Stratagene). Amplimers for the full-length Usurpin construct were 5'-GCG GAT CCT CTA GAC TCG AGC CAT GGC TGC TGA AGT CAT CCA TCA GGT TGA AGA AGC AC-3' (forward amplimer) and 5'-GCT CTA GAC TCG AGC CAT GGT TAT GTG TAG GAG AGG ATA AGT TTC-3' (reverse amplimer) resulting in the construct designated [Usurpin, $\left.\mathrm{Met}^{1}-\mathrm{Thr}^{480}\right]:[\mathrm{pBII} \mathrm{SK}+]:[\mathrm{Xbal}]:[\mathrm{T} 7]$ : [MF-UMP\#4556]. Amplimers for $\triangle D E D-A$ Usurpin were $5^{\prime}$-GCT CTA GAC TCG AGC CAT GGC AGA GAT TGG TGA GGA TTT GG-3' and the reverse amplimer described above, resulting in the construct designated [ $\triangle$ DED-A Usurpin, Met $\left.{ }^{97}-\mathrm{Thr}^{480}\right]:[\mathrm{pBII}$ SK+] : $[$ Xbal] : [T7]: [MF-UMP\#3712]. Amplimers for pro-Usurpin were $5^{\prime}$-GCT CTA GAC TCG AGC CAT GGC TTC AAA TAA CTT CAG GCT CCA TAA TGG-3' and the reverse amplimer described above, resulting in the construct designated $\left[\Delta\right.$ pro-Usurpin, MetAlaSer $\left.{ }^{198}-\mathrm{Thr}^{480}\right]$ : [pBII SK+]:[Xbal]: [T7]:[MF-UMP\#4225]. A similar approach was used to generate procaspase-8 (MACH/FLICE/Mch5) beginning with the amplimer $5^{\prime}$-GCT CTA GAG GAT CCA TGG ACT TCA GCA GAA ATC TTT ATG ATA TTG-3' (forward amplimer) plus 5'-GCT CTA GAG GAT CCA CAT GTT CAA TCA GAA GGG AAG ACA AGT TTT TTT CTT AG-3' (reverse amplimer) and resulting in the construct [pro-Caspase-8, Met ${ }^{1}$ $\left.\mathrm{Asp}^{479}\right]:[\mathrm{Xbal}]:[\mathrm{T7}]:[\mathrm{MF}-\mathrm{UMP} \# 4091]$. For the generation of radiolabeled polypeptides, purified plasmid DNA (Qiagen) was used to drive transcription (T7 polymerase) and coupled translation in rabbit reticulocyte lysates (Promega $\mathrm{TnT}$ ) in the presence of $\left[{ }^{35} \mathrm{~S}\right]$ methionine (>1000 Ci/mmol, Amersham). 
Constructs for expression in bacteria: Full length Usurpin, $\triangle \mathrm{DED}-\mathrm{A}$ Usurpin and $\Delta$ pro-Usurpin constructs that were generated for recombinant expression in bacteria were identical to those described above except that each contained the FLAG epitope tag (DYKDDDDK) at the carboxy terminus for purification and for immuno-immobilization in harvesting experiments. The forward amplimers in each case were identical to those described in the preceding section whereas a common reverse amplimer was used for all three constructs to introduce the FLAG epitope and the nested restriction sites (5'-CGT CTA GAC CAT GGT CAC TTG TCA TCG TCG TCC TTG TAG TCT GTG TAG GAG AGG ATA AGT TT-3'). All three clones were made as Xbal-Xhol-Ncol-(Usurpin construct-FLAG)-Ncol-Xhol-Xbal fragments that were subsequently purified from preparative agarose gels, trimmed with Xbal (Boehringer Mannheim) then ligated into the $X$ bal site of pBluescript II SK ${ }^{+}$and transformed into $E$. coli XL2-blue cells (Stratagene). After sequence verification, the constructs were excised with $\mathrm{Ncol}$ then ligated into the $\mathrm{Ncol}$ site of pET11d and transformed into BL21(DE3)pLysS E. coli cells (Novagen) after orientation and sequence re-verification. The resulting constructs were [Usurpin (Met $\left.{ }^{1}-\mathrm{Thr}^{480}\right)$-FLAG] :[pET11d]:[Ncol]: [T7/lac]: [MF-

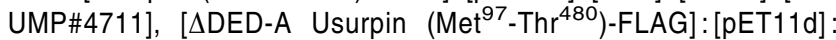
[Ncol]:[T7/lac]:[MF-UMP\#4320] and [ $\Delta$ pro-Usurpin (MetAlaSer ${ }^{198}$. Thr $\left.\left.{ }^{480}\right)-F L A G\right]$ : [pET11d]:[Ncol]: [T7/lac]: [MF-UMP\#4329]. A similar approach was used to generate recombinant FADD/MORT1 (containing the C-terminal streptavidin binding motif, SAYRHPQFGG) beginning with the amplimers 5'-CGT CTA GAC CAT GGA CCC GTT CCT GGT GCT GCT GCA CTC-3' (forward amplimer) plus 5'CGT CTA GAC CAT GGT CAA CCA CCG AAC TGC GGG TGA CGC CAA GCG CTG GAC GCT TCG GAG GTA GAT GCG TCT GAG-3' (reverse amplimer) and resulting in the construct [FADD/MORT1 $\left(\right.$ Met $^{1}-$ Ser $\left.^{256}\right)$-StrepTag] : [pET11d]:[T7/lac]: [MF-UMP\#4337]. In all cases, protein expression was initiated (in cells grown in $\mathrm{M} 9$ medium to an $\mathrm{OD}_{600 \mathrm{~nm}}=0.6$ ) with $1 \mathrm{mM}$ IPTG for $2 \mathrm{~h}$ at $30^{\circ} \mathrm{C}$.

Constructs for transfections into human cells: Full length Usurpin and $\triangle$ DED-A Usurpin were generated by PCR as BamHI-Xbal-XholNcol-(Usurpin)-Ncol-Xhol-Xbal and Xbal-Xhol-( $\triangle$ DED-A Usurpin)Xhol-Xbal fragments, respectively, using the amplimers 5'-GCG GAT CCT CTA GAC TCG AGC CAT GGC TGC TGA AGT CAT CCA TCA GGT TGA AGA AGC AC-3' (Usurpin forward amplimer) plus $5^{\prime}$-GCT CTA GAC TCG AGC CAT GGT TAT GTG TAG GAG AGG ATA AGT TTC-3' (Usurpin reverse amplimer), and 5'-GCT CTA GAC TCG AGG TGA TGG CAG AGA TTG GTG AGG ATT TGG ATA AAT C-3' ( $\triangle D E D$ A Usurpin forward amplimer) plus 5'-GCT CTA GAC TCG AGT TAT GTG TAG GAG AGG ATA AGT TTC TTT CTC-3' (DDED-A Usurpin reverse amplimer). The fragments were subsequently purified from preparative agarose gels, trimmed with $X b a l$ (Boehringer Mannheim) then ligated into the $X$ bal site of pBluescript II SK+ and transformed into $E$. coli XL2-blue cells (Stratagene). After sequence verification, the constructs were excised with Xbal (Usurpin) or Xhol ( $\triangle \mathrm{DED}-\mathrm{A}$ Usurpin) and ligated into the same restriction sites in pcDNA3 (Invitrogen). The resulting constructs were [Usurpin, Met ${ }^{1}$ $\left.\mathrm{Thr}^{480}\right]$ :[pcDNA3]: [Xbal]:[T7/CMV]:[MF-UMP\#4601] and [ODED-A Usurpin, Met ${ }^{97}-$ Thr $\left.^{480}\right]:[$ pcDNA3]: [Xhol] : [T7/CMV]: [MFUMP\#3466].

Retro-mutation of non-functional residues within Usurpin to their functional caspase counterparts: Analysis of the Usurpin sequence indicated that at least four critical determinants necessary for caspase proteolytic activity were absent, including the catalytic diad (Cys ${ }^{[I C E: 285]}$ and His ${ }^{[I C E: 237]}$, the former being harbored within the QACXG peptapeptide motif) and two of the four residues that tether the $\mathrm{P}_{1}$ Asp carboxylate side chain ( $\operatorname{Arg}^{[\mathrm{ICE}: 179}$ and $\left.\operatorname{Arg}^{[\mathrm{ICE}: 341]}\right)$. These residues were mutated to their counterparts within pro-caspase- 8 and -10 by oligonucleotide-mediated site-directed mutagenesis. Constructs were generated for expression in bacteria that included the full length Usurpin coding sequence ([Usurpin Met ${ }^{1}-T^{480}: C^{259} R$; $\mathrm{R}^{315} \mathrm{H} ; \quad$ QNYVV $\left.{ }^{358-362} \mathrm{QACQG} ; \mathrm{Q}^{415} \mathrm{R}\right]:[\mathrm{pET} 11 \mathrm{~d}]:[\mathrm{T} 7 / \mathrm{lac}]:[\mathrm{MF}-$ UMP\#4848]) or its equivalent lacking the prodomain ([ $\Delta$ pro-Usurpin MetAlaSer ${ }^{198}-\mathrm{Thr}^{480}: \mathrm{C}^{259} \mathrm{R} ; \mathrm{R}^{315} \mathrm{H} ; \mathrm{QNYVV}^{358-362} \mathrm{QACQG}$; $\left.\mathrm{Q}^{415} \mathrm{R}\right]$ : [pET11d]: [T7/lac] : [MF-UMP\#4876]) (data not shown).

\section{In vitro binding experiments}

Buffers used in these experiments include TE $(50 \mathrm{mM}$ Tris/ $\mathrm{HCl}$ (pH 8.0), $2 \mathrm{mM}$ EDTA), TENT (50 mM Tris/HCl (pH 8.0), 2 mM EDTA, $150 \mathrm{mM} \mathrm{NaCl}, 1 \%(\mathrm{v} / \mathrm{v})$ Triton X-100) and SRsBB $(20 \mathrm{mM}$ Tris/HCl (pH 7.5), $100 \mathrm{mM} \mathrm{NaCl}, 2 \mathrm{mM}$ EDTA, 0.1\% (v/v) Nonidet P-40, 5\% (v/ v) glycerol, $2 \mathrm{mM}$ dithiothreitol, $0.05 \%$ (w/v) bovine serum albumin). Recombinant proteins were generated by soluble expression in bacteria as described above. $\left.{ }^{35} \mathrm{~S}\right]$-Polypeptides were generated by coupled transcription/translation in reticulocyte lysates as described above but were spun for $30 \mathrm{~min}$ at $100000 \times \mathrm{g}$ prior to use to remove particulate matter.

Binding of $\left[{ }^{35} S\right]$-proteins to immobilized Usurpin constructs: AntiFLAG M2 affinity resin (anti-FLAG-epitope monoclonal antibodies covalently linked to agarose beads; $25 \mathrm{nmol} / \mathrm{ml}$ binding capacity; Kodak) was washed extensively with TENT buffer then combined with saturating quantities of bacterial lysates containing the indicated FLAG-epitope tagged Usurpin protein and incubated with constant shaking for $30 \mathrm{~min}$ at $4^{\circ} \mathrm{C}$. The beads were then washed by dilution/ centrifugation three times with 10 volumes of TENT buffer then three times with SRsBB buffer. The Usurpin loaded beads were suspended as a $50 \%$ slurry in SRsBB buffer then $125 \mu$ l of the $50 \%$ slurry was combined with $25 \mu \mathrm{l}$ of the indicated reticulocyte lysate and incubated for $2 \mathrm{~h}$ at $10^{\circ} \mathrm{C}$ with gentle mixing. At the end of the binding incubation, non-bound proteins were removed by washing the beads twice with $1 \mathrm{ml}$ (15 volumes) SRsBB buffer then three times with SRsBB containing $150 \mathrm{mM} \mathrm{NaCl}$. After removal of the final wash buffer, proteins were eluted from the beads with $40 \mu \mathrm{l}$ of Laemmli SDScontaining sample buffer followed by denaturation for $5 \mathrm{~min}$ at $95^{\circ} \mathrm{C}$. The resulting supernatants were resolved on SDS-polyacrylamide gels and the $\left[{ }^{35} \mathrm{~S}\right]$-proteins were visualized by fluorography of the dried gel.

Binding of $\left[{ }^{35}\right.$ S]-proteins to immobilized FADD/MORT1: Streptavidinagarose beads (Pierce) were washed extensively with TE buffer then combined with FADD/MORT1-StrepTag generated in bacteria, as described above, for $30 \mathrm{~min}$ at $4^{\circ} \mathrm{C}$ with constant shaking. The FADD/ MORT1-loaded beads were then washed by dilution/centrifugation three times with 10 volumes of TE buffer and suspended as a $50 \%$ slurry in TE. Binding reaction mixtures (250 $\mu$ l total volume) were prepared to contain $125 \mu \mathrm{l}$ of the $50 \%$ slurry of FADD/MORT1-loaded beads, $25 \mu$ l reticulocyte lysate containing [ ${ }^{35}$ S]pro-caspase- 8 and $100 \mu$ of the indicated amounts of recombinant Usurpin proteins in phosphate-buffered saline ( $\mathrm{pH} 7.4), 1 \%$ Triton X-100, 100 mM EDTA, $5 \mathrm{mM}$ dithiothreitol. In a competition format, the $\left[{ }^{35} \mathrm{~S}\right]$ pro-caspase-8 was combined with the recombinant Usurpin for $15 \mathrm{~min}$ at $4{ }^{\circ} \mathrm{C}$ before the addition of the FADD/MORT1-loaded beads. In a displacement format, the FADD/MORT1-loaded beads were first combined with the ${ }^{35}$ S]pro-caspase-8 for $15 \mathrm{~min}$ at $4^{\circ} \mathrm{C}$ prior to the addition of the recombinant Usurpin. All mixtures were then incubated for $2 \mathrm{~h}$ at $4^{\circ} \mathrm{C}$ with gentle mixing and subsequently washed three times with $1 \mathrm{ml}$ (15 volumes) TE buffer. After removal of the final wash supernatant, the complexes were eluted by the addition of $30 \mu \mathrm{l}$ of $1 \mathrm{mM} \mathrm{d}$-biotin (in TE buffer) to the $62.5 \mu \mathrm{l}$ bed volume of beads. After $30 \mathrm{~min}$ on ice, the 
resulting supernatants were recovered following centrifugation and combined with SDS-containing Laemmli sample buffer, resolved on SDS-polyacrylamide gels and the $\left[{ }^{35}\right.$ S]pro-caspase- 8 that was harvested was visualized by fluorography of the dried gel. For quantitative analysis, band volumes on the fluorographs were quantified by laser densitometry.

\section{Transfections, stable cell lines and apoptosis measurement}

Stable transfection of HeLa cells: Adherent HeLa cells were plated at $5 \times 10^{5}$ cells per $60 \mathrm{~mm}$ dish in Dulbecco's Modified Eagle's Media supplemented with L-glutamine, penicillin, streptomycin, and 10\% (v/v) fetal bovine serum and grown overnight at $37^{\circ} \mathrm{C}$ with $5 \% \quad \mathrm{CO}_{2}$. Following this re-plating incubation, the cells were transfected using calcium phosphate with $15 \mu \mathrm{g}$ of either vector DNA (pcDNA3) or the vector harboring $\triangle \mathrm{DED}-\mathrm{A}$ Usurpin. Bulk-stable cell lines were established by placing cells under G418 selection (at $0.4 \mathrm{mg} / \mathrm{ml}$ ) $48 \mathrm{~h}$ post-transfection, and maintaining the selection continuously for 6 weeks prior to assaying for anti-apoptotic effects. Stably transfected cells were plated in 96-well plates at $1 \times 10^{4}$ cells/well and grown overnight. Cells were then treated with anti-CD95 (Fas/APO-1) monoclonal antibody (clone $\mathrm{CH}-11$; MBL International) at concentrations ranging from $0-0.1 \mathrm{mg} / \mathrm{ml}$ (done in triplicate for each cell line) and incubated $16 \mathrm{~h}$. The number of viable cells remaining was determined using the Cell Titre-96 (Promega) MTT reagent (3-(4,5dimethylthiazol-2-yl)-2,5-diphenyltetrazolium bromide). Viable cells were indicated by their ability to convert the MTT tetrazolium salt into its formazan counterpart which absorbs at $570 \mathrm{~nm}$.

Transient transfection of Jurkat cells: Cultured Jurkat cells were harvested by centrifugation then suspended in medium at $4 \times 10^{6}$ cells $/ 0.4 \mathrm{ml}$ and co-transfected by electroporation $(1050 \mu \mathrm{F}, 720 \Omega$, $260 \mathrm{~V})$ with $1 \mu \mathrm{g}$ of an Aequorea victoria green fluorescent protein (GFP) expression vector (GFP : pcDNA3) plus $5 \mu \mathrm{g}$ of either Usurpin in pcDNA3 or the pcDNA3 vector alone. Three to six independent transfections were typically pooled and used $12 \mathrm{~h}$ later for experiments. Transfected cells were purified on a Ficol gradient immediately prior to testing and were screened for transfection efficiency (typically $30-45 \%$ ) by Facs analysis (FL-1 positive cells indicating the presence of GFP). The cells were aliquoted into wells in 96-well plates $\left(5 \times 10^{4}\right.$ cells per $200 \mu \mathrm{l}$ well) then treated with antiCD95 (Fas/APO-1) monoclonal antibody (clone $\mathrm{CH}-11$; $\mathrm{MBL}$ International) at $0.5-1 \mu \mathrm{g} / \mathrm{ml}$ for the indicated length of time. After stimulation, cells of duplicate wells were harvested and resuspended in Facs buffer for analysis of either propidium iodide staining or Annexin- $V$ binding as indicated.

\section{Generation of Usurpin and caspase antisera}

The $\triangle D E D-A$ Usurpin fragment harbored within the construct [ $\triangle D E D-A$ Usurpin, Met $\left.^{97}-\mathrm{Thr}^{480}\right]$ : [pBII SK+]:[Xbal] : [T7] : [MF-UMP\#3712] (described above) was excised from nested $\mathrm{Ncol}$ sites and ligated into pET11d as described above for other bacterial expression constructs. (The resulting construct is designated [ $\triangle \mathrm{DED}-\mathrm{A}$ Usurpin $\left.\left(\mathrm{Met}^{97}-\mathrm{Thr}^{480}\right)\right]:[\mathrm{pET11d}]:[\mathrm{Ncol}]:[\mathrm{T7} / \mathrm{lac}]:[\mathrm{MF}-U M P \# 3827]$ and differs from those described above in that there is no FLAG epitope tag.). Expression of $\triangle D E D-A$ Usurpin and accumulation in inclusion bodies was induced by overnight culture at $37^{\circ} \mathrm{C}$ of BL21(DE3)pLysS cells (harboring this vector) in M9 medium containing $1 \mathrm{mM}$ IPTG. The inclusion bodies (in which $\triangle D E D-A$ Usurpin was the only identifiable protein) were purified, denatured in $6 \mathrm{M}$ guanidine $\mathrm{HCl}, 25 \mathrm{mM}$ Tris $(\mathrm{pH} 7.4)$ and used directly for immunization of rabbits. Antisera were raised against the large subunit of caspase-3 $\left(\right.$ Metser $^{29}$-Asp ${ }^{175}$ ) and caspase-8 $\left(\right.$ MetSer $^{217}$-Asp ${ }^{374}$ ) in an identical manner. For generating an antisera that preferentially recognizes the mature, active form of caspase-3 (used in Figure 10c), rabbits were immunized with crystallographic-grade, tetrameric caspase-3 enzyme that was generated exactly as described before for the determination of the X-ray crystal structure of human caspase-3 (Rotonda et al, 1996).

\section{Immunohistochemical localization of Usurpin in rat heart}

Tissue preparation: Experiments were approved by the Animal Care Committee at the Merck Frosst Centre for Therapeutic Research in accordance with the guidelines established by the Canadian Council on Animal Care. Male Sprague Dawley rats $(250-400 \mathrm{~g})$ were used and were anesthetized with intraperitoneal pentobarbital $(65 \mathrm{mg} / \mathrm{kg})$. Heart rate, aortic pressure and a Lead II electrocardiograph were continuously recorded. A left thoracotomy was performed in the region overlying the heart and a suture was passed under the left coronary artery (LCA) and used to occlude the artery. The LCA was occluded for $45 \mathrm{~min}$ and reperfused for $3 \mathrm{~h}$ following release of the suture. At the end of reperfusion, rats were euthanized by pentobarbital overdose, and the heart was rapidly excised and flushed with $20 \mathrm{ml} 0.9 \%$ sodium chloride. The heart was slowly (over 3-4 min) infused with $40 \mathrm{ml}$ of $10 \%$ buffered formalin phosphate and fixed overnight $(18 \mathrm{~h})$ in $10 \%$ buffered formalin phosphate, after which the heart was transferred to $70 \%$ ethanol. After paraffin embedding, serial cross sections from heart blocks were cut and fixed to glass slides for immunohistochemical study.

Immunohistochemical detection of Usurpin: A primary polyclonal antibody raised against recombinant human Usurpin (described above) was used to study the localization of rat cardiac Usurpin. The primary antibody was visualized indirectly using an $A B C$ technique, whereby positive Usurpin immunoreactivity was evident by a red fluorescent signal. Apoptotic myocytes were identified with a commercially available TUNEL (terminal deoxynucleotidyl-transferase nick-end labeling) labeling kit (Oncor). The TUNEL reaction labels apoptotic nuclei by means of a terminal dideoxynucleotidyl transferase (TdT)-catalyzed addition of a digoxigenin-tagged nucleotide to the free 3'-OH end of nicked DNA. Labeled DNA was visualized with an FITC coupled anti-digoxigenin secondary antibody, yielding bright yellow/ green nuclei.

Western blotting for Usurpin in infarcted versus non-infarcted regions: Following $45 \mathrm{~min}$ ischemia and $3 \mathrm{~h}$ of reperfusion, the heart was rapidly removed and flushed of blood with $10 \mathrm{ml}$ saline. The heart was then perfused with $10 \mathrm{ml} 1.5 \%$ triphenyltetrazolium chloride (TTC) at $37^{\circ} \mathrm{C}$ incubated at room temperature for 2 minutes to allow for staining of the viable tissue and differentiation of the ischemic/ reperfused region. The heart was cut into $2 \mathrm{~mm}$ transverse sections from the site of occlusion to the apex, and dissected into infarcted and non-infarcted regions. Heart tissue was frozen in liquid nitrogen and stored at $-80^{\circ} \mathrm{C}$. Frozen tissue sections were weighed on dry ice, and immediately placed in cold homogenization buffer $(25 \mathrm{mM}$ Tris $/ \mathrm{HCl}$ (pH 7.5), 10 mM EGTA, 5 mM EDTA, 0.5 mM phenylmethylsulfonylfluoride, $0.01 \mathrm{mg} / \mathrm{ml}$ leupeptin, $0.01 \mathrm{mg} / \mathrm{ml}$ aprotinin, $5 \mathrm{mM}$ dithiothreitol, $1 \%(\mathrm{v} / \mathrm{v})$ Triton X-100), adding $6 \mathrm{ml}$ buffer per gram of tissue. Tissue was cut into small pieces with fine scissors and then homogenized on ice. Homogenates were sonicated on ice at $50 \mathrm{~Hz}$, $45 \mathrm{~A}$ for three cycles of $10 \mathrm{~s}$, then centrifuged at $4^{\circ} \mathrm{C}$ at $18000 \mathrm{xg}$ for $30 \mathrm{~min}$. Following protein determination, identical quantities of protein were resolved on SDS (10-20\%) polyacrylamide gradient gels, 
transferred to nitrocellulose by electroblotting then probed for Usurpin using the antibody described above with enhance chemiluminescence (ECL) detection.

\section{Acknowledgements}

F.H. is supported by the Albert-Ludwigs-University of Freiburg, Germany

\section{References}

Alnemri ES, Livingston DJ, Nicholson DW, Salvesen G, Thornberry NA, Wong WW and Yuan J (1996) Human ICE/CED-3 protease nomenclature [letter]. Cell 87: 171

Bauer MK, Wesselborg S and Schulze-Osthoff K (1997) The Caenorhabditis elegans death protein Ced-4 contains a motif with similarity to the mammalian 'death effector domain'. FEBS Lett 402: 256-258

Bertin J, Armstrong RC, Ottilie S, Martin DA, Wang Y, Banks S, Wang GH, Senkevich TG, Alnemri ES, Moss B, Lenardo MJ, Tomaselli KJ and Cohen JI (1997) Death effector domain-containing herpesvirus and poxvirus proteins inhibit both Fasand TNFR1-induced apoptosis. Proc Natl Acad Sci USA 94: 1172-1176

Boldin MP, Goncharov TM, Goltsev YV and Wallach D (1996) Involvement of MACH, a novel MORT1/FADD-interacting protease, in Fas/APO-1- and TNF receptorinduced cell death. Cell 85: 803-815

Boldin MP, Varfolomeev EE, Pancer Z, Mett IL, Camonis JH and Wallach D (1995) A novel protein that interacts with the death domain of Fas/APO1 contains a sequence motif related to the death domain. J Biol Chem 270: 7795-7798

Bump NJ, Hackett M, Hugunin M, Seshagiri S, Brady K, Chen P, Ferenz C, Franklin S, Ghayur T, Li P, et al (1995) Inhibition of ICE family proteases by baculovirus antiapoptotic protein p35. Science 269: 1885-1888

Chinnaiyan AM, O'Rourke K, Tewari M and Dixit VM (1995) FADD, a novel death domain-containing protein, interacts with the death domain of Fas and initiates apoptosis. Cell 81: 505-512

Cohen GM. (1997) Caspases: the executioners of apoptosis. Biochem J 326:1-16.

Devereaux QL, Takahashi R, Salvesen GS and Reed JC. (1997) X-linked IAP is a direct inhibitor of cell-death proteases. Nature 388: $300-304$

Fernandes-Alnemri T, Armstrong RC, Krebs J, Srinivasula SM, Wang L, Bullrich F, Fritz LC, Trapani JA, Tomaselli KJ, Litwack G and Alnemri ES (1996) In vitro activation of CPP32 and Mch3 by Mch4, a novel human apoptotic cysteine protease containing two FADD-like domains. Proc Natl Acad SciUSA 93: 74647469

Goltsev YV, Kovalenko AV, Arnold E, Varfolomeev EE, Brodianskii VM and Wallach D (1997) CASH, a novel caspase homologue with death effector domains. J Biol Chem 272: 19641-19644

Gottlieb RA, Burleson KO, Kloner RA, Babior BM and Engler RL (1994) Reperfusion injury induces apoptosis in rabbit cardiomyocytes. J Clin Invest 94: 1621 - 1628

Han DKM, Chaudhary PM, Wright ME, Friedman C, Trask BJ, Riedel RT, Baskin DG, Schwartz SM and HoodL (1997) MRIT, a novel death-effector domain-containing protein, interacts with caspases and BcIXL and initiates cell death. Proc Natl Acad Sci USA 94: 11333-11338

Hara H, Friedlander RM, Gagliardini V, Ayata C, Fink K, Huang Z, Shimizu-Sasamata M, Yuan J and Moskowitz MA (1997) Inhibition of interleukin 1beta converting enzyme family proteases reduces ischemic and excitotoxic neuronal damage. Proc Natl Acad Sci USA 94: 2007-2012

Hu S, Vincenz C, Buller M and Dixit VM (1997) A novel family of viral death effector domain-containing molecules that inhibit both $\mathrm{CD}$-95- and tumor necrosis factor receptor-1-induced apoptosis. J Biol Chem 272: 9621-9624

Hu S, Vincenz C, Ni J, Gentz R and Dixit VM (1997) I-FLICE, a novel inhibitor of tumor necrosis factor receptor-1- and CD-95-induced apoptosis. J Biol Chem 272: $17255-17257$

Inohara N, Koseki T, Hu Y, Chen S and Nunez G (1997) CLARP, a death effector domain-containing protein interacts with caspase-8 and regulates apoptosis. Proc Natl Acad Sci USA 94: 10717-10722

Ioannou PA, Amemiya CT, Garnes J, Kroisel PM, Shizuya H, Chen C, Batzer MA and de Jong PJ (1994) A new bacteriophage P1-derived vector for the propagation of large human DNA fragments. Nat Genet 6: 84-89

Irmler M, Thome M, Hahne M, Schneider P, Hofmann K, Steiner V, Bodmer JL, Schroter M, Burns K, Mattmann C, Rimoldi D, French LE and Tschopp J (1997) Inhibition of death receptor signals by cellular FLIP. Nature 388: 190-195
Kajstura J, Cheng W, Reiss K, Clark WA, Sonnenblick EH, Krajewski S, Reed JC, Olivetti $G$ and Anversa P (1996) Apoptotic and necrotic myocyte cell deaths are independent contributing variables of infarct size in rats. Lab Invest 74: 86-107

Kerr JF, Wyllie AH and Currie AR (1972) Apoptosis: a basic biological phenomenon with wide-ranging implications in tissue kinetics. Br J Cancer 26: 239-257

Kuida K, Zheng TS, Na S, Kuan C, Yang D, Karasuyama H, Rakic P and Flavell RA (1996) Decreased apoptosis in the brain and premature lethality in CPP32deficient mice. Nature 384: $368-372$

Liston P, Roy N, Tamai K, Lefebvre C, Baird S, Cherton-Horvat G, Farahani R, McLean M, Ikeda JE, MacKenzie A and Korneluk RG (1996) Suppression of apoptosis in mammalian cells by NAIP and a related family of IAP genes. Nature 379: $349-353$

Loddick SA, MacKenzie A and Rothwell NJ (1996) An ICE inhibitor, z-VAD-DCB attenuates ischaemic brain damage in the rat. Neuroreport 7: 1465-1468

McConkey DJ, Zhivotovsky B and Orrenius S (1996) Apoptosis-molecular mechanisms and biomedical implications. Mol Aspects Med 17: 1-110

Medema JP, Scaffidi C, KischkelFC, Shevchenko A, Mann M, KrammerPHand Peter ME (1997) FLICE is activated by association with the CD95 death-inducing signaling complex (DISC). Embo J 16: 2794-2804

Muzio M, Chinnaiyan AM, Kischkel FC, O'Rourke K, Shevchenko A, Ni J, Scaffidi C, Bretz JD, Zhang M, Gentz R, Mann M, Krammer PH, Peter ME and Dixit VM (1996) FLICE, a novel FADD-homologous ICE/CED-3-like protease, is recruited to the CD95 (Fas/APO-1) death -inducing signaling complex. Cell 85, 817-827

Nagata S (1997) Apoptosis by death factor. Cell 88: 355-365

Nicholson DW, Ali A, Thornberry NA, Vaillancourt JP, Ding CK, Gallant M, Gareau Y, Griffin PR, Labelle M, Lazebnik YA, et al (1995) Identification and inhibition of the ICE/CED-3 protease necessary for mammalian apoptosis. Nature 376: 37-43

Nicholson DW and Thornberry NA (1997) Caspases: killer proteases. Trends Biochem Sci 22: 299-306

Rano TA, Timkey T, Peterson EP, Rotonda J, Nicholson DW, Becker JW, Chapman KT and Thornberry NA (1997) A combinatorial approach for determining protease specificities: application to interleukin-1 beta converting enzyme (ICE). Chem Biol 4: 149-155

Rosen A and Casciola-Rosen L (1997) Macromolecular substrates for the ICE-like proteases during apoptosis. J Cell Biochem 64: 50-54

Rotonda J, Nicholson DW, Fazil KM, Gallant M, Gareau Y, Labelle M, Peterson EP, Rasper DM, Ruel R, Vaillancourt JP, Thornberry NA and Becker JW (1996) The three-dimensional structure of apopain/CPP32, a key mediator of apoptosis. Nat Struct Biol 3: 619-625

Rowen L and Koop BF (1994) In Automated DNA sequencing and analysis, M. D. Adams, C. Fields and J. C. Venter, eds. (San Diego: Academic Press)

Sharov VG, Sabbah HN, Shimoyama H, Goussev AV, Lesch M and Goldstein S (1996) Evidence of cardiocyte apoptosis in myocardium of dogs with chronic heart failure. Am J Pathol 148: 141-149

Shu HB, Halpin DR and Goeddel DV (1997) Casper is a FADD- and caspase-related inducer of apoptosis. Immunity 6: 751-763

Srinivasula SM, Ahmad M, Ottilie S, Bullrich F, Banks S, Wang Y, Fernandes-Alnemri T, Croce CM, Litwack G, Tomaselli KJ, Armstrong RC and Alnemri ES (1997) FLAME-1, a novelFADD-like anti-apoptotic molecule that regulates Fas/TNFR1induced apoptosis. J Biol Chem 272: 18542-18545

Steller $\mathrm{H}$ (1995) Mechanisms and genes of cellular suicide. Science 267: 1445-1449

Thome M, Schneider P, Hofmann K, Fickenscher H, Meinl E, Neipel F, Mattmann C, Burns K, Bodmer JL, Schroter M, Scaffidi C, KrammerPH, PeterME and Tschopp $J$ (1997) Viral FLICE-inhibitory proteins (FLIPs) prevent apoptosis induced by death receptors. Nature 386: 517-521

Thompson CB (1995) Apoptosis in the pathogenesis and treatment of disease. Science 267: $1456-1462$

Thornberry NA, Rano TA, Peterson EP, Rasper DM, Timkey T, Garcia-Calvo M, Houtzager VM, Nordstrom PA, Roy S, Vaillancourt JP, Chapman KT and Nicholson DW (1997) A combinatorial approach defines specificities of members of the caspase family and granzyme $B$. Functional relationships established for key mediators of apoptosis. J Biol Chem 272: 17907-17911

Uren AG and VauxDL (1996) Molecular and clinical aspects of apoptosis. Pharmacol Ther 72: $37-50$

Van Criekinge W, BeyaertR, Van de Craen M., Vandenabeele P, Schotte P, De Valck D and Fiers W (1996) Functional characterization of the prodomain of interleukin1beta- converting enzyme. J Biol Chem 271: 27245-27248 
Vincenz C and Dixit VM (1997) Fas-associated death domain protein interleukin1beta-converting enzyme 2 (FLICE2), an ICE/Ced-3 homologue, is proximally involved in CD95- and p55-mediated death signaling. J Biol Chem 272: 65786583

Walker NP, Talanian RV, Brady KD, Dang LC, Bump NJ, Ferenz CR, Franklin S, Ghayur T, Hackett MC, Hammill LD, et al. (1994) Crystal structure of the cysteine protease interleukin-1 beta- converting enzyme: a (p20/p10)2 homodimer. Cell 78: $343-352$

Wallach D, Boldin M, Varfolomeev E, BeyaertR, Vandenabeele P and Fiers W (1997) Cell death induction by receptors of the TNF family: towards a molecular understanding. FEBS Lett 410: 96-106
Wilson KP, Black JA, Thomson JA, Kim EE, Griffith JP, Navia MA, Murcko MA, Chambers SP, Aldape RA, Raybuck SA, et al. (1994) Structure and mechanism of interleukin- 1 beta converting enzyme [see comments]. Nature 370: 270-275 Xue D and Horvitz HR (1995) Inhibition of the Caenorhabditis elegans cell-death protease CED-3 by a CED-3 cleavage site in baculovirus p35 protein. Nature 377: $248-251$

Yuan J (1997) Transducing signals of life and death. Curr Opin Cell Biol 9: 247-251

Zhou Q, Snipas S, Orth K, Muzio M, Dixit VM and Salvesen GS (1997) Target protease specificity of the viral serpin CrmA. Analysis of five caspases. J Biol Chem 272: 7797-7800 